新規遺伝子発現制御化合物としてのピロールポリアミドーヌクレオシドハイブリッド及び そのハイブリッドを組込んだオリゴマーの設計，合成及び評価

川島悦子, * 釜池和 大

\title{
Design, Synthesis and Evaluation of Polyamide-nucleoside Hybrids and Oligonucleotides Conjugated Hybrid as a Novel Gene Expression Control Compound
}

\author{
Etsuko KAWASHIMA* and Kazuo KAMAIKE \\ School of Pharmacy, Tokyo University of Pharmacy and Life Sciences, \\ 1432-1 Horinouchi, Hachioji, Tokyo 192-0392, Japan
}

(Received July 31, 2009)

\begin{abstract}
On the basis of reports that a minor groove binder pyrrolepolyamide can interfere with gene expression by the sequence-specific recognition of DNA, we expected that nucleoside bearing a pyrrolepolyamide would be able to regulate gene expression. Therefore, we designed and synthesized the pyrrolepolyamide-adenosine (Hybrid 1) and -2' -deoxyguanosine hybrids (Hybrid 2 and Hybrid 3) as lead compounds for gene expression control compounds. The pyrrolepolyamide frame of Hybrid 2 and Hybrid 3 combines at the 2-exocyclic amino group of the $2^{\prime}$-deoxyguanosine by a linker and the 2-exocyclic amino group of guanine exists in the minor groove side of the duplex. Hybrid 2 is the $2^{\prime}$-deoxyguanosine-pyrrolepolyamide hybrid using the 3-aminopropionyl linker, while Hybrid $\mathbf{3}$ uses the 3-aminopropyl linker. An evaluation of the DNA binding sequence selectivity was performed by analysis of $T_{\mathrm{m}}$ values and CD spectra, using distamycin A as a contrast. Hybrid 3 has provided more excellent sequence-distinguishable ability than other hybrids and Distamycin A. Moreover, on the basis of these results, we synthesized oligonucleotides conjugated to Hybrid 4, which is stable under conditions of DNA oligonucleotide solid phase synthesis, arranged from Hybrid 3. From $T_{\mathrm{m}}$ values and CD spectral analysis, it was found that oligonucleotides conjugating Hybrid 4 possess high recognition ability and very high binding ability for the DNA that includes the pyrrolepolyamide binding sequence.
\end{abstract}

Key words— - gene expression control; MGB-nucleoside hybrid; DNA-oligomer conjugated hybrid

\section{はじめに}

地球上に存在する生命は，細菌から人間，植物に 至るまですべての生物において，DNA や RNA と 呼ばれる共通の分子を用いて，遺伝情報を後世へと 伝達している。また，生物が生存していくために必 要な多様な生命現象も DNA や RNA によってコン トロールされている，遺伝子工学の発展に伴い，が んを含む様々な疾病が遺伝子レベルで理解され，さ らに感染症を引き起こす細菌やウィルスが持つゲノ ムの解析も急速に進んでいる.

悪性新生物に関しては，長年に渡り日本における 病死による死因の第一位となっており，遺伝子の塩

東京薬科大学薬学部（干192-0392 東京都八王子市堀之 内 1432-1)

*e-mail: kawasima@toyaku.ac.jp

本総説は, 平成 20 年度退職にあたり在職中の業績を中 心に記述されたものである。
基配列に欠損や置換などなんらかの変異が存在する ことが原因となり発症することが明らかにされてい る。現在使われている抗がん剂には核酸誘導体が多 く利用されており，分裂周期の早いがん細胞と正常 細胞との核酸の需要の差を用いることで，相対的に 正常細胞への影響を抑えている. しかし，実際毛髪 や爪などの細胞分裂が盛んな部位には比較的早期に 副作用があらわれ，造血系，消化器系にも深刻な影 響を与えることが多く，抗がん剂を用いる化学療法 の大きな問題点として挙げられている.

一方，社会的問題となっている HIV を含む様々 なウィルスによる感染症は, 現在使用されている薬 剂に対する耐性菌の出現により感受性の低下が危惧 されている.

がん細胞やウィルスの持つ独自の遺伝子や疾病の 原因となる特定遺伝子の発現を選択的に抑制する方 法は，各種疾病の画期的かつ根治的な治療法となる 
ことが期待できる．このことから，特定の遺伝子の 塩基配列を認識しその発現を阻害できる化合物の開 発が望まれている.

このような化合物に求められる特性は, 1) 1）各々 の細胞内の標的遺伝子を特定するために十分な長さ の塩基配列を厳密に識別できる，2）標的遺伝子の 塩基配列に対してのみ高い親和性を有する，3）化 学的合成が容易である，4）生体内の各種酵素の存 在下において安定である，5）細胞毒性が低い, 6）細胞膜，核膜を容易に透過できる，7）一度の作 用で失活せず，繰り返し多数の細胞に作用（ターン オーバー）する，ことが求められる.

また標的となる遺伝子には，A，二重鎖 DNA (複製及び転写の開始を阻害：アンチジーン法), ${ }^{2)}$ B. 一本鎖 DNA（転写の阻害 : アンチセンス法), ${ }^{3}$ C. mRNA（翻訳の阻害：アンチセンス法，RNAi 法),4)などが挙げられる.

アンチセンス法は，標的遺伝子の一本鎖 DNA や mRNA に対してなんらかの修飾を施した相補的な 配列のオリゴヌクレオチド（アンチセンス核酸）を 投与し，結合させることで，複製，転写，翻訳を阻 害，あるいは RNase H による分解を促すことによ り，がん細胞や細菌，さらにはウィルスに対して増 殖抑制効果を発揮する方法である. アンチセンス法 に用いられる化合物としては, リン酸基の酸素原子 1 つを同族原子である硫黄に置き換えたホスホロチ オエート型のオリゴヌクレオチドが特に広く研究さ れている. 5)これは(1)RNase H による分解活性，(2) ヌクレアーゼ而性，(3)細胞膜透過性，(4)水溶性にお いて優れており，その他の糖部や塩基部の修飾と組 み合わせて用いることも可能であり，利便性が高い．

FDA（米国食品医薬品局）により初のアンチセン スドラッグとして，サイトメガロウィルスによる網 膜炎に対する適用で認可されたものもホスホロチオ エート型オリゴヌクレオチド (21-mer) (Vitravene ${ }^{\circledR}$, Isis Pharm. Inc.) であり，最近では筋ジストロフ イーに対する効果も報告されている。 ${ }^{6)}$ 一方, 遺伝 子の二重鎖 DNA を直接標的としたアンチジーン法 は，オリゴヌクレオチドを用い，二重鎖 DNA に対 して三重鎖核酸を形成させることにより当該遺伝子 の発現を制御しようというものである。この方法 は，アンチセンス法に比べて技術的な制約が多いこ とから（標的配列がホモプリンーホモピリミジンに

限定される，三重鎖核酸の安定性が不十分等)，そ れらを克服するための研究が行われている.

ほかにも糖部フラノース環のパッカリングを $3^{\prime}$ endo 型（ $N$ 型）に固定し mRNA との親和性を高 めた BNA（Bridged Nucleic Acid) ${ }^{7)}$ や，塩基部位に スタッキング効果を増強させるような置換基を導入 したもの, ${ }^{8)}$ 主鎖を糖ではなくアミド結合の高分子 に置き換えた PNA (Peptide Nucleic Acid) ${ }^{9)}$ などが 治療薬の候補として挙げられているが, 現在はまだ 研究段階である。 DNA を用いる治療法は, 遺伝子 以外に転写調節因子と呼ばれるタンパク質の配列認 識部位を標的とし，その作用を阻害するデコイ（お とり）型 DNA を用いる遺伝子治療にも関心が集ま つている. ${ }^{10)}$ 近年注目を集めている遺伝子を用いた 技術として RNA 干渉（RNA interference: RNAi） 法4)がある。実際の応用には, 細胞内に任意の配列 を持つ二重鎖 RNA（dsRNA）を直接導入するか, ベクターを用いて in vivo で発現させればよいが, RNA の安定性に多少の問題は残る.

このように，核酸あるいはその誘導体は元来から 有する塩基配列選択性，標的遺伝子への親和性を生 かし，医薬品へと応用することが可能である.

一方, 核酸誘導体ではないものの, 塩基配列選択 的に遺伝子に作用する化合物もいくつか知られてい る。細菌から単離された抗生物質であるディスタマ イシン A (Fig. 1) は, 配列にアデニン（A）若し くはチミン（T）が 3 個以上連続した二重鎖 DNA の熱力学的安定性を向上させる. ディスタマイシン $\mathrm{A}$ は，その弓なりの分子構造が B 型 DNA の副溝 (minor groove) の湾曲にマッチし，内側を向いた わずかに酸性度を有する $\mathrm{NH}$ 基がアデニンの $N 3$ 位，あるいはチミンの $C 2$ 位のカルボニル酸素との 水素結合を介することで分子間の結合を安定化させ ている．配列にグアニン $(\mathrm{G})$-シチジン $(\mathrm{C})$ 塩基 対が存在すると, 副溝側に突き出したグアニンの $C 2$ 位のアミノ基と 1-メチルピロール（Py）のC3 位の水素の間に立体的な障害があり，副溝に対する

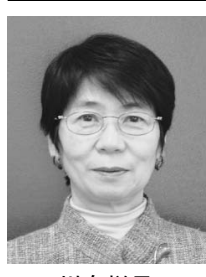

川島悦子
東京薬科大学. 客員教授. 東京薬科大 学卒. 東京薬科大学助手, 薬学博士取 得 (東北大学), アメリカミシガン大 学薬学部博士研究員, 講師, 助教授を 経て東京薬科大学教授, 2009 年定年退 職. 退職後, 東京薬科大学客員教授と して現在に至る。 


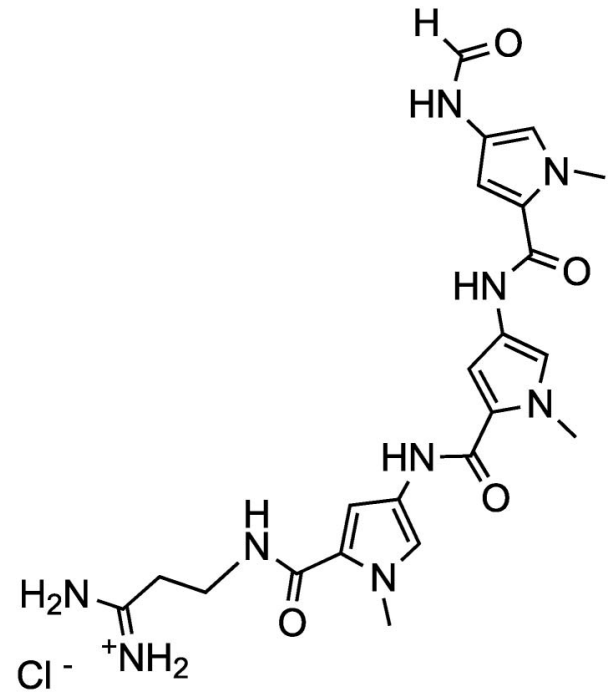

Fig. 1. Structure of Distamycin A
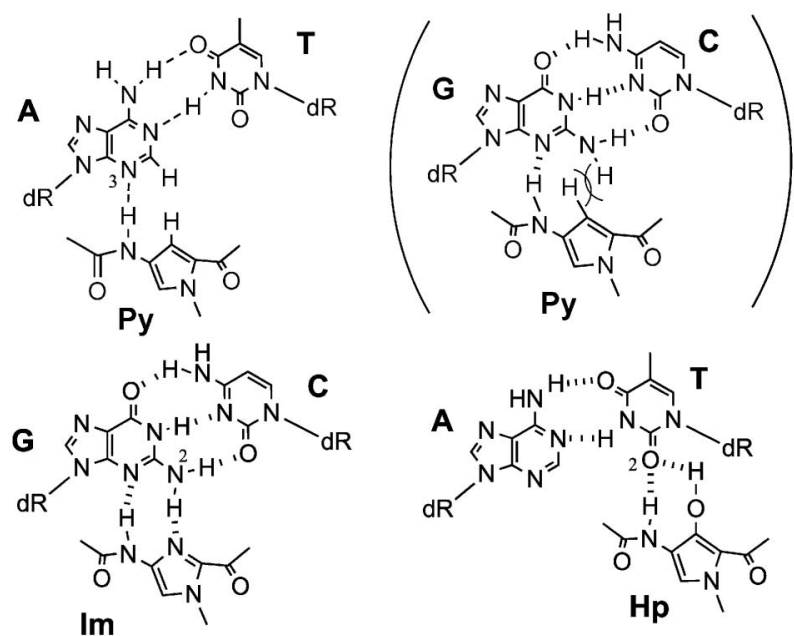

$\mathrm{dR}=2^{\prime}$-deoxyribose

Fig. 2. Representation of the Binding of Pyrrole Amide, Imidazole Amide and Hydroxypyrrole Amide to DNA

親和性が低下することから塩基配列選択性があらわ れている (Fig. 2). 11)のちの研究からディスタマイ シン A は 1 つマッチサイトに対して逆平行に 2 分子配位していることが明らかにされ，さらに逆平 行に配向したディスタマイシン $\mathrm{A}$ 誘導体の 1-メチ ルピロールを1-メチルイミダゾール（Im）や3-ヒ ドロキシ-1-メチルピロール（Hp）に置き換えるこ とで，4つの塩基対の組み合わせ（A-T, T-A, G-C, C-G）すべてを認識することが可能になった（Fig. 2). ${ }^{12)}$

Dervan らは，逆平行に配向する Py-Im ポリアミ ド化合物をリンカーで結合し二重鎖 DNA への配列
選択性と親和性を向上することに成功している (Fig. 3).13) しかし，ヒドロキシピロール（Hp）は 化合物に問題があり，遺伝子発現の制御などの応用 にはあまり利用されていない. ${ }^{14)}$

任意の塩基配列を認識するポリアミド化合物は固 相法による自動合成法が確立され, ${ }^{15)}$ 標的とする塩 基配列に適合する化合物を容易に合成できる利便性 の高さ，さらに核酸誘導体で問題となるヌクレアー ゼに対する安定性，細胞膜や核膜に対する透過性も 優れていることから, ${ }^{16)}$ 新たな塩基配列認識分子と して関心が高まっている。このポリアミド化合物を 用いた研究としては，Dervan とその共同研究者が 多くの論文を発表している.中でも Dervan らは Zn フィンガータンパクである TFIIIA の認識配列の 4 番目のフィンガーの結合配列である $5^{\prime}$-AGTACT-3' を標的とするへアピンポリアミドを合成し, TFIIIA の結合を阻害することにより 5S-rRNA 遺伝子の転 写の選択的抑制に成功している. ${ }^{17)}$ また Dervan ら はポリアミド化合物を利用したホモダイマーにより 16 塩基対を認識する Minor Groove Binder (MGB)

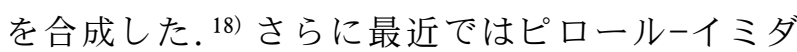
ゾールポリアミドをエチレングリコール誘導体（89 メチレンリンカー) でリンクし，ヘアピン型を固 定した MGB が dsDNA 5'-ACGCGT-3'サイトと高 い親和性（ $\Delta T_{\mathrm{m}}>30^{\circ} \mathrm{C} ）$ を有するとの報告を Hartley らが報告している. ${ }^{19)}$ Sekine らはリンカーにフ エロセンを用いたへアピン型ピロールーイミダゾー ルポリアミドの合成と特性を報告している。

また配列選択的 MGB ポリアミドに機能性分子を 結合させ，その機能を標的遺伝子に対して塩基配列 選択的に発現させようとする試みも数多くなされて いる．代表的な例はブレオマイシン, ${ }^{21)}$ ナイトロジ エンマスタード, ${ }^{22)}$ シクロプロピルインドール, ${ }^{23)}$ DNA インターカレーター, ${ }^{24)}$ デュオカルマイシ ン25,26)を機能性分子として用いたものである. 中で も Sugiyama らはデュオカルマイシン及びその誘導 体と MGB ポリアミドのハイブリッド化合物を，任 意の標的塩基配列に選択的に作用させることに成功 している26)。 また Romagnol らは天然物において重 要な機能性構造である細胞毒性セスキテルペンの $\alpha-$ メチレン- $\gamma$-ブチロラクトンをピロールポリアミド

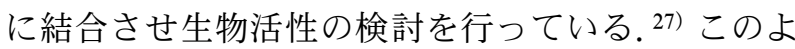
うに MGB ポリアミドは機能性分子の持つ薬理活性 


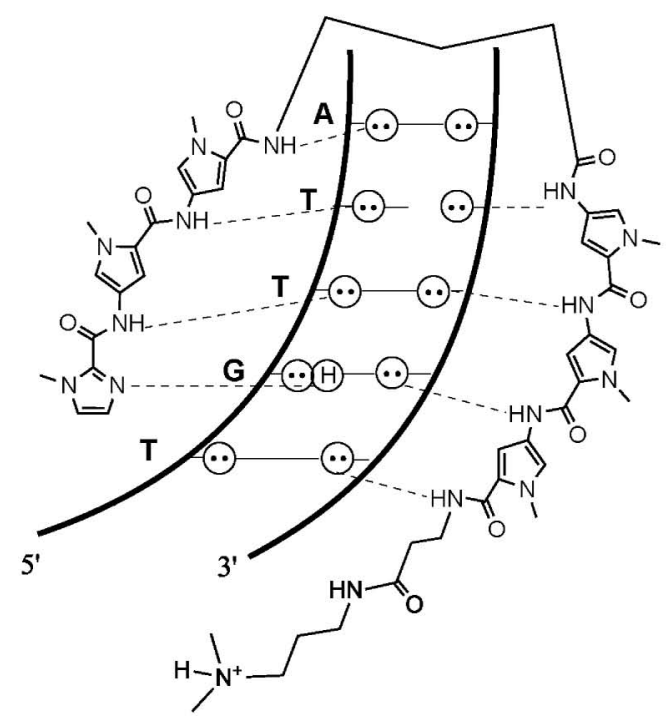

Py / Py targets A - T and T / A

$\longleftrightarrow$ Py / Py targets A - T and T / A

$\longleftrightarrow$ Im / Py targets G - C

Fig. 3. The Hairpin Motif

The amino and carboxy terminus of the antipararellel dimers are connected by $\gamma$-aminobutyric acid $(\gamma)$.

を保持したまま，ユニークな塩基配列認識能を付加 できることが明らかにされている.

以上の背景をもとに, ゲノム化学に基づく遺伝情 報制御分子の創製を目的として，MGB ポリアミド ーヌクレオシドハイブリッド化合物の設計を考案し た.

ハイブリッド化合物の活性発現機構のコンセプト を下記に示す (Fig. 4).

コンセプト A ：MGB ポリアミドーヌクレオシド ハイブリッド化合物が単体で二重鎖 DNA に作用す る場合には，ハイブリッド中のヌクレオシドが Hoogsteen 型の水素結合を形成し，さらに MGB ポ リアミドによる親和性，核酸塩基配列選択性を発揮 するようなアンチジーン的作用を持つことが考えら れる。

コンセプト B : これらのハイブリッド化合物は, 通常の核酸や抗がん剂などに用いられる修飾ヌクレ オシドと同様に生合成経路で DNA 内に取り込まれ た場合，その近辺の配列にMGB ポリアミドの標的 となるマッチサイトが存在すると非常にタイトで安 定した副溝への結合を形成することで二重鎖 DNA の安定化を示し，その DNA の複製や転写を阻害す るものと考えられる。，一方，近辺にMGB ポリアミ ドにとってミスマッチなサイトが存在した際には二 重鎖の安定化作用を示さないことから複製や転写を 阻害しないことが期待できる.

コンセプト C : MGB ポリアミドーヌクレオシド

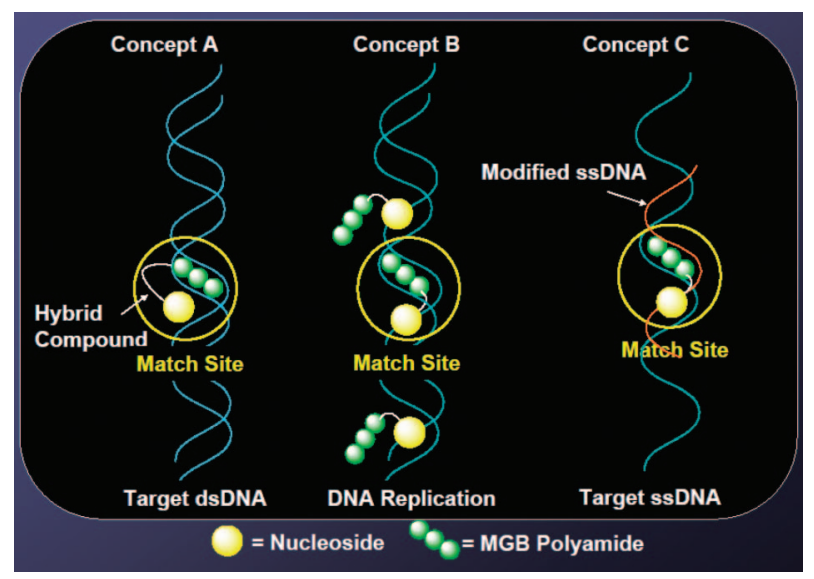

Fig. 4. Concept of the Activity Expression Mechanism of Hybrids

ハイブリッド化合物を DNA 内に組込んだ場合 (modified ssDNA)，標的である 1 本鎖 DNA との 二重鎖を厳密な塩基配列選択能を有するようになり， DNA ばかりでなく， RNA にも作用するアンチセ ンスオリゴヌクレオチドとしての役割を担わせるこ とも可能となる (Fig. 4).

そこで，1.コンセプト A 及び B に基づく MGB ポリアミドーヌクレオシドハイブリッド化合物の設 計と合成，ハイブリッドと二重鎖 DNA（dsDNA） との相互作用の評価，2．コンセプト B を期待し て，生合成されるであろう modified ssDNA 及びコ ンセプト C に基づく MGB ポリアミドーヌクレオシ ドハイブリッド化合物を組み込んだオリゴヌクレオ 
チド鎖（modified ssDNA）の合成及びその相補鎖 （ssDNA）との相互作用の評価及び活性評価等を行 つた.

本稿ではそれらの検討経過と成果について概説さ せて頂きたい.

1. MGB ポリアミドーヌクレオシドハイブリッド 化合物の設計，合成及び dsDNA に対する選択的相 互作用の評価 ${ }^{28}$

1-1. MGB ポリアミドーヌクレオシドハイブリッ ド化合物の設計 ゲノム解析のツールや核酸医薬 品としてヌクレオシドを用いる場合，天然の構造の 一部を改変する，又は新たな機能性分子を化学的に 付加する必要がある．核酸分子と様々な機能性分子 との結合は，それぞれの持つ欠点を補い，長所を併 せ持った新しい化合物へと発展することが可能であ る.

MGB ポリアミドは様々な機能性分子とハイブリ ッドさせることでそれらの持つ薬理活性を保持した ままユニークな塩基配列認識能を付加することが可 能である，さらに，MGB ポリアミドはその高い塩 基配列認識能に加え生体内酵素に対する高い安定 性，優れた膜透過性を有するため，MGB ポリアミ ドとのハイブリッド化合物はこれらすべての特徵を 併せ持つことが期待できる. ヌクレオシドと MGB ポリアミドとのハイブリッド化合物は，DNA 内に 組込まれることで活性を示すことが期待される。 そ のためこのハイブリッド化合物は, 生体内でのヌク レオシド部位の挙動がその未修飾体の挙動を損なわ ず，結合した機能性分子の特徵がよりよく生かされ る構造を設計しなければならない.

MGB ポリアミドーヌクレオシドハイブリッド化 合物を設計するにあたり，まず MGB ポリアミドが DNA 二重鎖に結合したときの立体構造を参考にヌ クレオシドへの最適な MGB ポリアミド導入部位の 検討を行った。 Wemmer らのディスタマイシン A のマッチサイトを含む DNA ドデカマーとディスタ マイシン A を結合させた複合体の ${ }^{1} \mathrm{H}-\mathrm{NMR}$ による 詳細な解析 ${ }^{29)}$ やDickerson らの X 線結晶構造解 析11a)により，ディスタマイシン A は二重鎖の副溝 に核酸塩基との水素結合によって配位していること が判明している。生合成により MGB ポリアミドー ヌクレオシドハイブリッド化合物を取り込んだ DNA が標的 DNA と二重鎖を形成する際，その安
定性を向上させるには，MGB ポリアミドが二重鎖 DNA 中の副溝側に位置するヌクレオシド部位に導 入されていることが重要である。この位置としては 副溝側に位置する RNA 糖部の 2 位のヒドロキシ基 が相当する．また核酸塩基部を考えると，ピリミジ ン塩基では $C 2$ 位と $N 3$ 位，プリン塩基では $C 2$ 位 であり,グアニン塩基には $C 2$ 位に副溝側に突き出 したアミノ基（N2 位）が存在する（Fig. 5)。そこ でRNA としてアデノシンの糖部の $2^{\prime}$ 位のヒドロキ シ基，また DNA ではグアノシンの環外アミノ基を 利用することで，容易かつ適切な部位での MGB ポ リアミドの修飾を行えると考えた。

MGB ポリアミド部分は，アデニン (A) -チミン （ $\mathrm{T}$ ）塩基対を含む配列を標的塩基配列とし，また 長さは DNA の湾曲に最も歪みなく挿入されるピ ロールアミド 3 量体（ピロールポリアミド）とし た. ${ }^{11)} N$ 末端のアミノ基の保護基には配位の際に立 体障害の少ないホルミル基を選択した。ピロールポ リアミドとヌクレオシドをつなぐリンカーとして は，適度な自由度を持たせるために適切な長さのア ルキル鎖がふさわしいと思われる。ピロールポリア ミドとの結合とグアニンの環外アミノ基への導入等 の合成上の利点を考慮しアルキル鎖の末端に第 1 ア ミンを有するカルボン酸である $\beta$-アラニン $(\mathrm{C} 3)$ を用いることとし， RNA の糖部 $2^{\prime}$ 位のヒドロキシ 基にピロールポリアミドをリンクさせた Hybrid 1 及びグアノシンの環外アミノ基にピロールポリアミ ドを $\beta$-アラニンでリンクさせた Hybrid 2 を考案し た.

さらに Hybrid 2 ではグアノシンの環外アミノ基 とリンカーの結合様式が保護基として一般に用いら れるアミド結合であり安定性に問題が残る。そこで 安定に存在できる結合様式として $2^{\prime}$-デオキシグア ノシンの環外アミノ基に直接アルキル鎖を導入した Hybrid 3 を設計した（Fig. 6).

1-2. ピロールポリアミドーヌクレオシドハイブ リッド化合物の合成

1-2-1. ピロールポリアミド部位の合成ディ スタマイシン A や MGB ポリアミドの合成は今ま でに数々の例が報告されている. ${ }^{30,31)}$ 中でも Dervan らは長鎖 MGB ポリアミドの自動合成法を確立 し, ${ }^{13)}$ それに伴いこれら関連化合物の DNA 認識に 関する研究は大きな進展をみせた。 

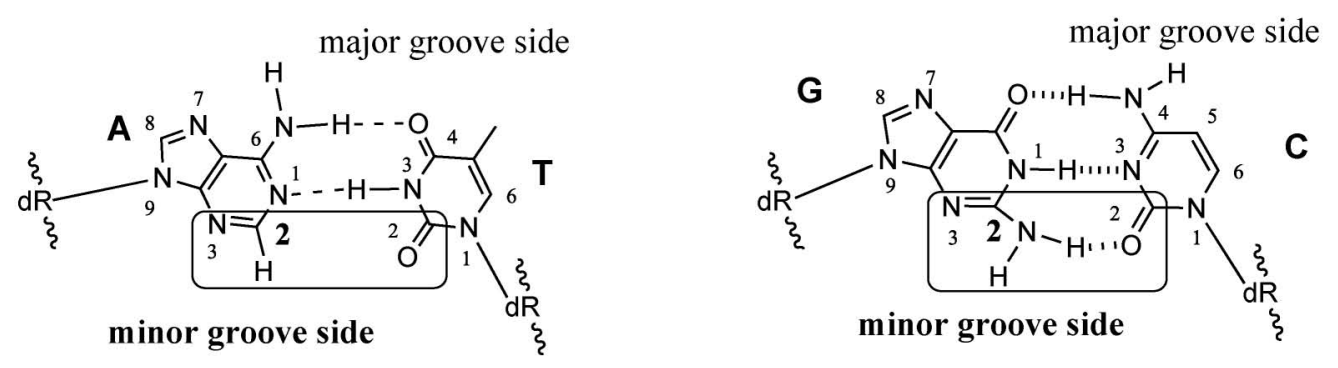

$\mathrm{dR}=2^{\prime}$-deoxyribose

Fig. 5. Representation of Double Strand DNA

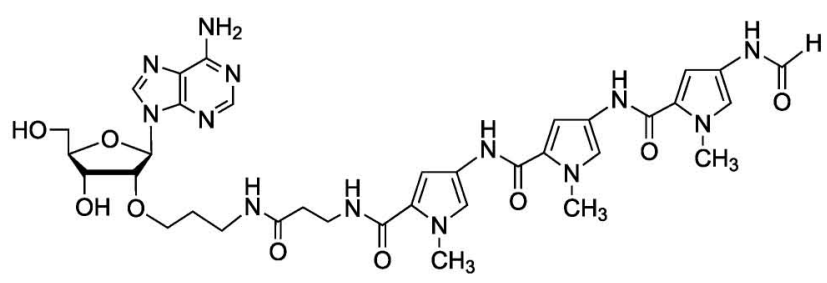

Hybrid 1

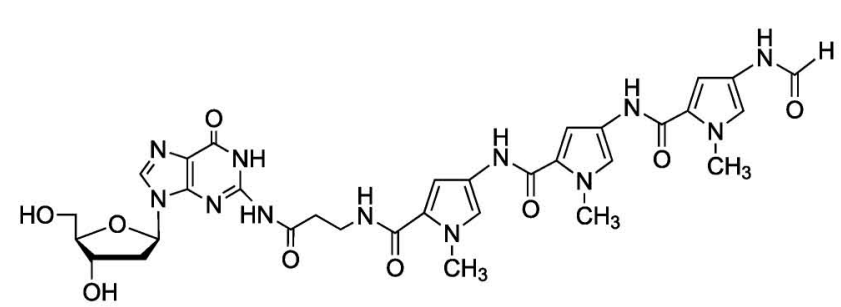

Hybrid 2

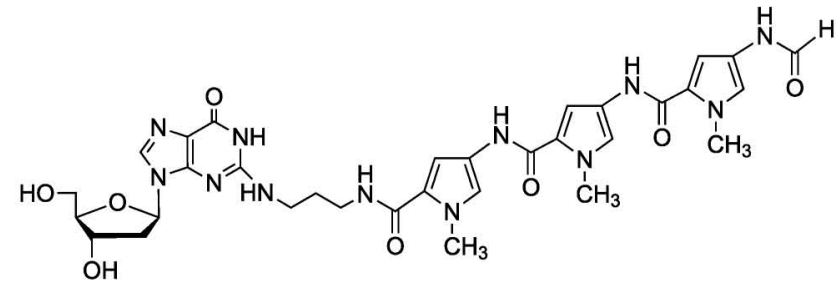

Hybrid 3

Fig. 6. Structures of Hybrid 1, Hybrid 2 and Hybrid 3

固相担体を用いるこの方法は簡便かつ迅速に長鎖 のポリアミド化合物を合成できるが，一方で合成用 の装置が必要であり目的のポリアミドを高収率で得 るために大過剩の反応試剂及び試薬を要するといつ たデメリットもある，一方，Boger らは液相法によ る効率的なディスタマイシン A 及びその誘導体の 合成を報告している. ${ }^{32}$ 本研究の目的とする短鎖の ポリアミドの合成には Boger らによって報告され た液相合成法が適切だと考え，この方法を応用しピ ロールポリアミド部の合成を行うこととした.

まず，1-methylpyrrole（1）を出発原料としピロー ルポリアミドの基本骨格となる 5 を 1 から 6 段階 64\%の収率で得た（Scheme 1).13)

次に，4 のニトロ基を接触還元によりアミノ基と し, カルボン酸 $\mathbf{5}$ との縮合によりピロールアミド 2 量体である 6 とした. 続いて, 6 の Boc 基を酸性条 件下で除去し, 再びカルボン酸 5 との縮合を行うこ
とによりピロールアミド 3 量体 7 を 4 段階 $97 \%$ の 収率で得た（Scheme 2).

この合成法では, 縮合試薬に 1-エチル-3-(3-ジメ チルアミノプロピル）カルボジイミド塩酸塩 （EDCI）を用いたことで，反応生成物を酸-塩基に よる分液操作のみで精製でき, それ以上の精製操作 が必要ないため, 非常に高収率で目的物 7 を得るこ とができた。

続いて, 7 の $C$ 末端のエステル部を加水分解しカ ルボン酸 8 へと変換した後, エチル $\beta$-アラニンと の縮合反応を行うことで 8 とエチル $\beta$-アラニンと の縮合体 9 を得た。エチルエステル 9 の加水分解, 続いて $N$ 末端の脱保護, 生じた第 1 アミンのホル ミル化により $\beta$-アラニンをリンカーとして有する ピロールアミド 3 量体 11 の合成をメチルエステル 7 から 5 段階 53\%の収率で達成した（Scheme 3).

1-2-2. ピロールポリアミドーアデノシン（Hybrid 


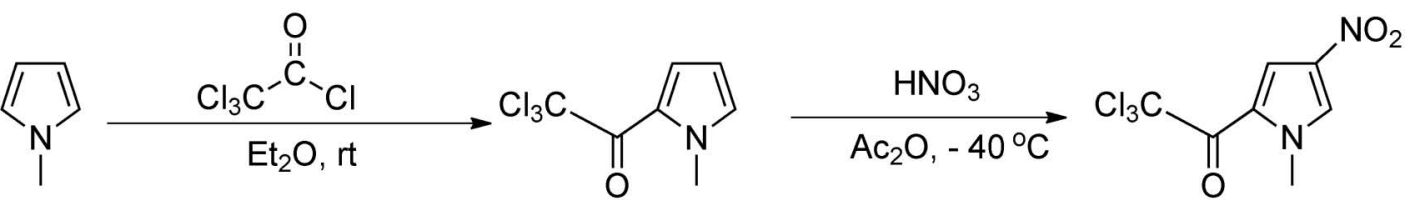

1

$296 \%$

$378 \%$

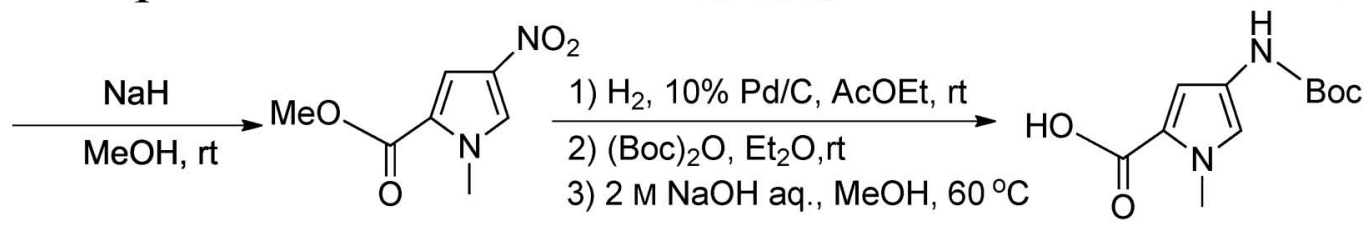

Scheme 1.

1) $\mathrm{H}_{2}, 10 \% \mathrm{Pd} / \mathrm{C}, \mathrm{AcOEt}$, rt 4 2) $5, \mathrm{EDCl}, \mathrm{DMAP}, \mathrm{DMF}$, rt<smiles>COC(=O)c1cc(NC(=O)c2cc(NC(=O)OC(C)(C)C)cn2C)cn1C</smiles><smiles>COC(=O)c1cc(NC(=O)c2cc(NC(=O)c3cc(NC(=O)OC(C)(C)C)cn3C)cn2C)cn1C</smiles>

Scheme 2 .

$7 \frac{2 \mathrm{M} \mathrm{NaOH} \text { aq. }}{\mathrm{MeOH}, 60^{\circ} \mathrm{C}}$<smiles></smiles>

8 quanut.<smiles>COO[14C](=O)OCCCNC(=O)c1cc(NC(=O)c2cc(NC(=O)c3cc(NC(=O)OC(C)(C)C)cn3C)cn2C)cn1C</smiles>

$1074 \%$

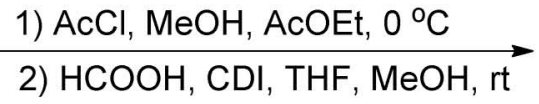

$9 \quad 85 \%$<smiles>[R18]C1CCCC1</smiles><smiles>C1=CN=CC1</smiles>

$\frac{\text { Ethyl } \beta \text {-alanine, EDCI, DMAP }}{\text { DMF, rt }}$<smiles>CCOC(=O)CCNC(=O)c1cc(NC(=O)c2cc(NC=O)cn2C)cn1C</smiles><smiles>CN1CCN(C(=O)c2ccccc2NC(=O)c2cc(NC(=O)c3cc(C(=O)NCCC(=O)O)nn3C)cn2C)C1</smiles>

Scheme 3. 
1）の合成アデノシンの糖部の $2^{\prime}$ 位のヒドロキ シ基にピロールポリアミドを結合させたアデノシン 一ハイブリッド化合物（Hybrid 1) の合成 ${ }^{33)}$ を行つ た.

アデノシンの糖部 $2^{\prime}$ 位ヒドロキシ基への 3-フ夕 ルイミドイルプロピル基の導入に関しては既に

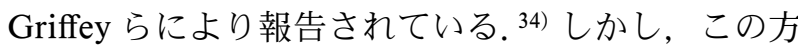
法は $3^{\prime}$ 位及び $5^{\prime}$ 位のヒドロキシ基の保護を行わず にアデノシンに直接 $N$-(3-ブロモプロピル) フタル イミドを反応させており，その収率は $17 \%$ であ る。そこで収率向上を目指して保護基の検討を行つ たが，3-フタルイミドイルプロピル基の導入効率の 向上はできなかった。そこで Griffey らと同様にア デノシンの糖部 2 位のヒドロキシ基に 3-フタルイ ミドイルプロピル基を導入し，ついで TIPDS-ジク ロライドを作用させて 13 を得た。続いて，13 をヒ ドラジンで処理しアミノプロピルエーテル 14 を得 た後，ジシクロヘキシルカルボジイミド（DCC）, 1-ヒドロキシベンゾトリアゾール $(\mathrm{HOBT})$ の存在 下 $\mathbf{1 1}$ との縮合を行い 15 に誘導した。最後に, 15
の脱保護を行い Hybrid 1 を得た（Scheme 4).

1-2-3. $\beta$-アラニンをリンカーとしたピロールポ リアミド-2'-デオキシグアノシンハイブリッド （Hybrid 2）の合成次に塩基配列認識能を有す る新たな機能性分子として $2^{\prime}$-デオキシグアノシン の $N 2$ 位にアミド結合によってピロールポリアミド を導入したピロールポリアミド-2'-デオキシグアノ シンハイブリッド化合物 Hybrid 2 の合成を検討し た.

3', 5'-O-TIPDS-2'-デオキシグアノシン 16 の N2 位アミノ基とカルボン酸 11 の縮合では，EDCI や DCC/HOBT などの縮合剂を用いた反応は全く進行 せず，原料を回収するのみであった（Scheme 5).

これは嵩高い分子同士の立体障害によりアミノ基 とカルボン酸の活性エステル体が空間的に近づき難 いか，プリン塩基による共鳴効果によりアミノ基の 求核性が充分でなかったことが原因ではないかと推 測した。 そこで，次に反応性の高い酸塩化物による アミド結合の形成を試みた。しかし，11 の酸塩化 物化の反応条件下においてピロールポリアミドの

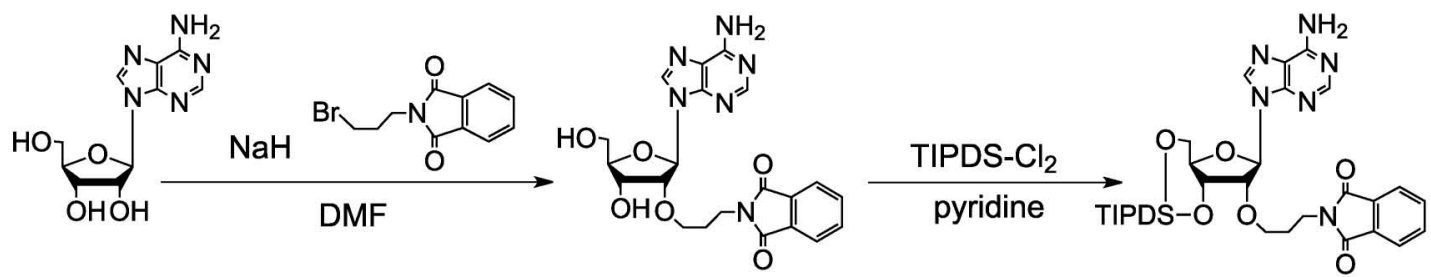

adenosine

12 crude

$1310 \%$ (from adenosine)

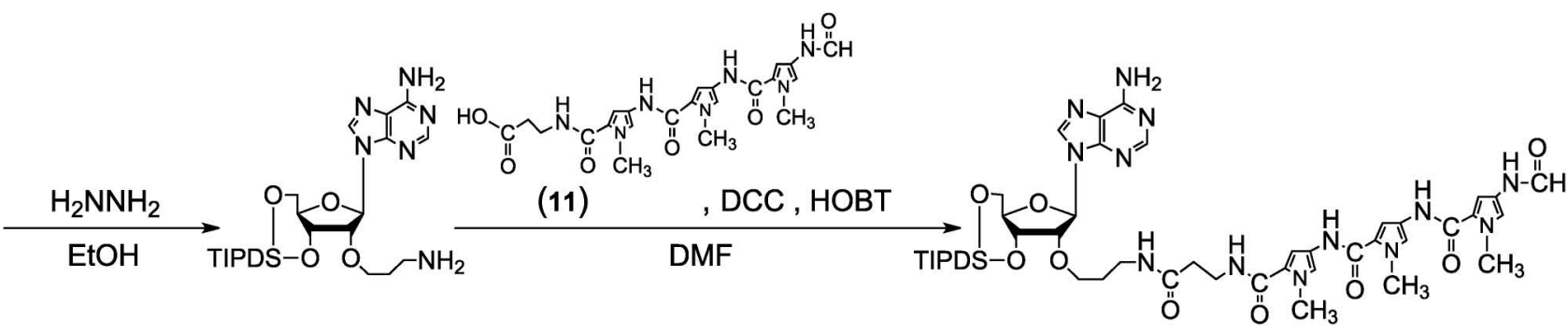

$1496 \%$

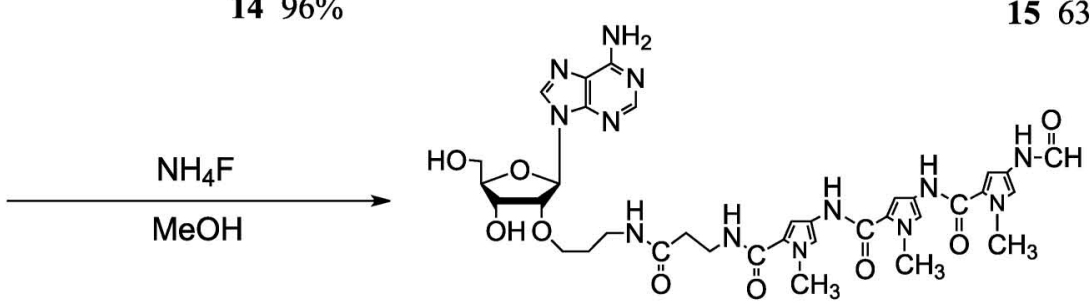

Hybrid 1 94\%

Scheme 4 . 


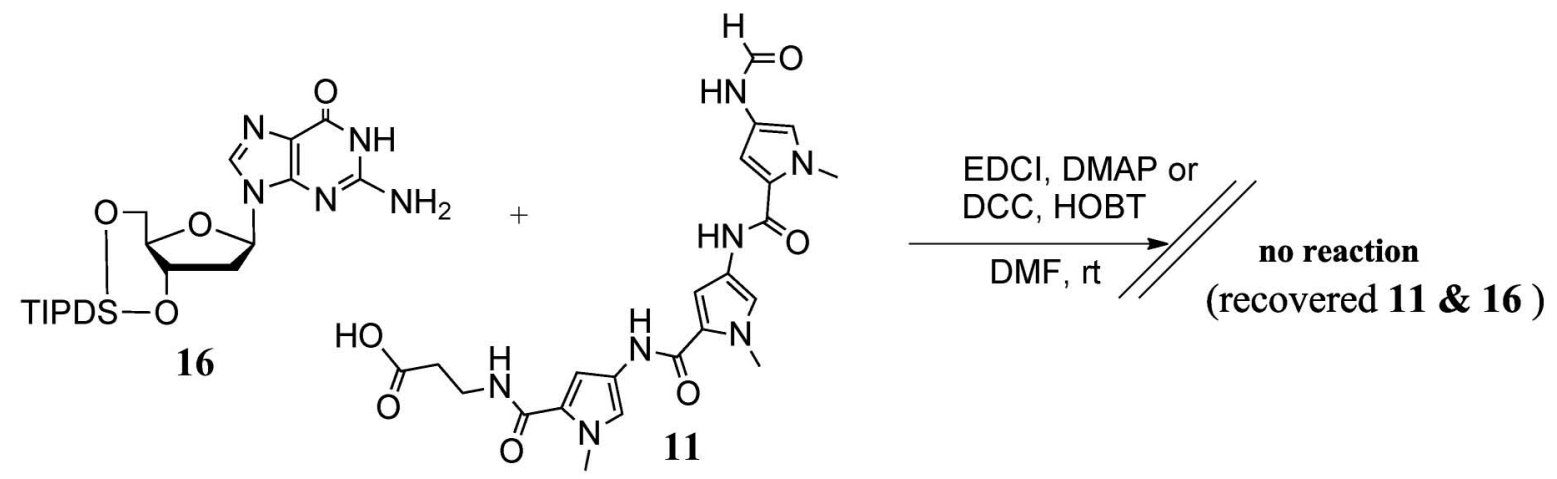

Scheme 5 .

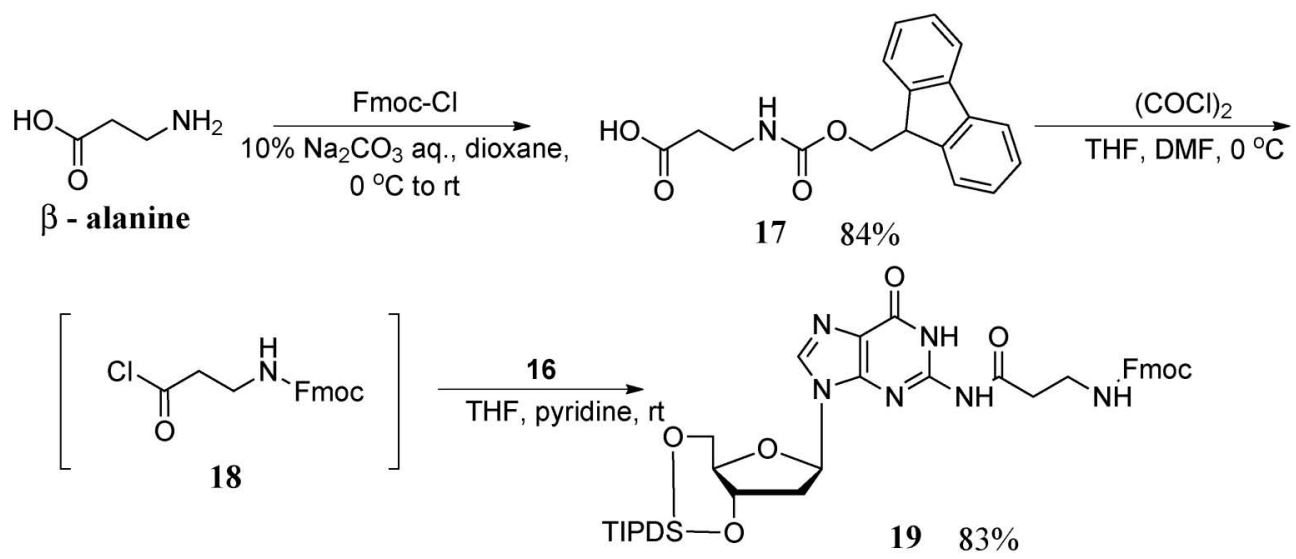

Scheme 6.

$N$ 末端に存在するホルミル基の安定性に問題があ ったため目的とする化合物を得ることはできなかっ た.

グアニン塩基の $N 2$ 位アミノ基は通常のアミノ基 より求核性が低いことが予測される。そこで立体障 害の少ない反応性の高い試薬として，N末端を保 護した $\beta$-アラニンの酸塩化物を用いてまず $N 2$ 位 アミノ基にリンカー部を導入したグアノシン誘導体 の合成を検討した（Scheme 6).

$\beta$-アラニンの $N$ 末端の保護基は，(1)アミノ基へ の導入が容易に行える，(2)酸塩化物への変換条件に 安定である, (3)2'-デオキシグアノシン誘導体が酸 性条件下で脱プリン反応を起こし易いため，酸性条 件以外で除去できるなどの条件を満たすことが必要 である．これらの条件を満たすものとして，本検討 では 9-フルオレニルメトキシカルボニル（Fmoc） 基を選択した。 Fmoc 基は，UV 吸収があるため TLC による反応の追跡を行い易いといった利点も あり，本合成に適していると考えた。
まず， $\beta$-アラニンの $N$ 末端を Fmoc-Cl を用いて $\beta$-アラニンの Fmoc 化体 $\mathbf{1 7}$ へと収率 $84 \%$ で変換し た．続いて，塩化オキザリルを用いて酸塩化物 ${ }^{35)}$ と し，この THF 溶液を $\mathbf{1 6}$ のピリジン溶液中に滴下 することで 16 の $N 2$ 位にリンカーとして $\beta$-アラニ ンを導入した 2 -デオキシグアノシン誘導体 19 を収 率 $83 \%$ で得た（Scheme 6).

一方，カルボン酸 8 の $N$ 末端の Boc 基を酸性条 件下で除去し，生じたアミノ基をホルミル化し，8 の末端がホルミル化された 20 を収率 $57 \%$ で得た (Scheme 7).

なお，この反応の際 20 の末端のカルボキシ基が ない化合物が得られたことから，この反応の収率の 低下はカルボン酸 $\mathbf{2 0}$ が脱炭酸した副生物が生じた ことに起因すると推測される.

次に，2'-デオキシグアノシン誘導体 19 の Fmoc 基をピペリジンを用いて脱保護し，減圧下でピペリ ジンを除去した後，精製することなくEDCI を用 いてカルボン酸 20 との縮合を行ったところ 21 を得 
<smiles>Cn1cc(NC(=O)c2cc(NC(=O)c3cc(NC(=O)OC(C)(C)C)cn3C)cn2C)cc1C(=O)O</smiles>

8

1) $\mathrm{AcCl}, \mathrm{MeOH}, \mathrm{AcOEt}, 0^{\circ} \mathrm{C}$<smiles>[CH]C(=O)Nc1cc(C(=O)Nc2cc(C(=O)Nc3cc(C(=O)O)n(C)c3)n(C)c2)n(C)c1</smiles>

Scheme 7.

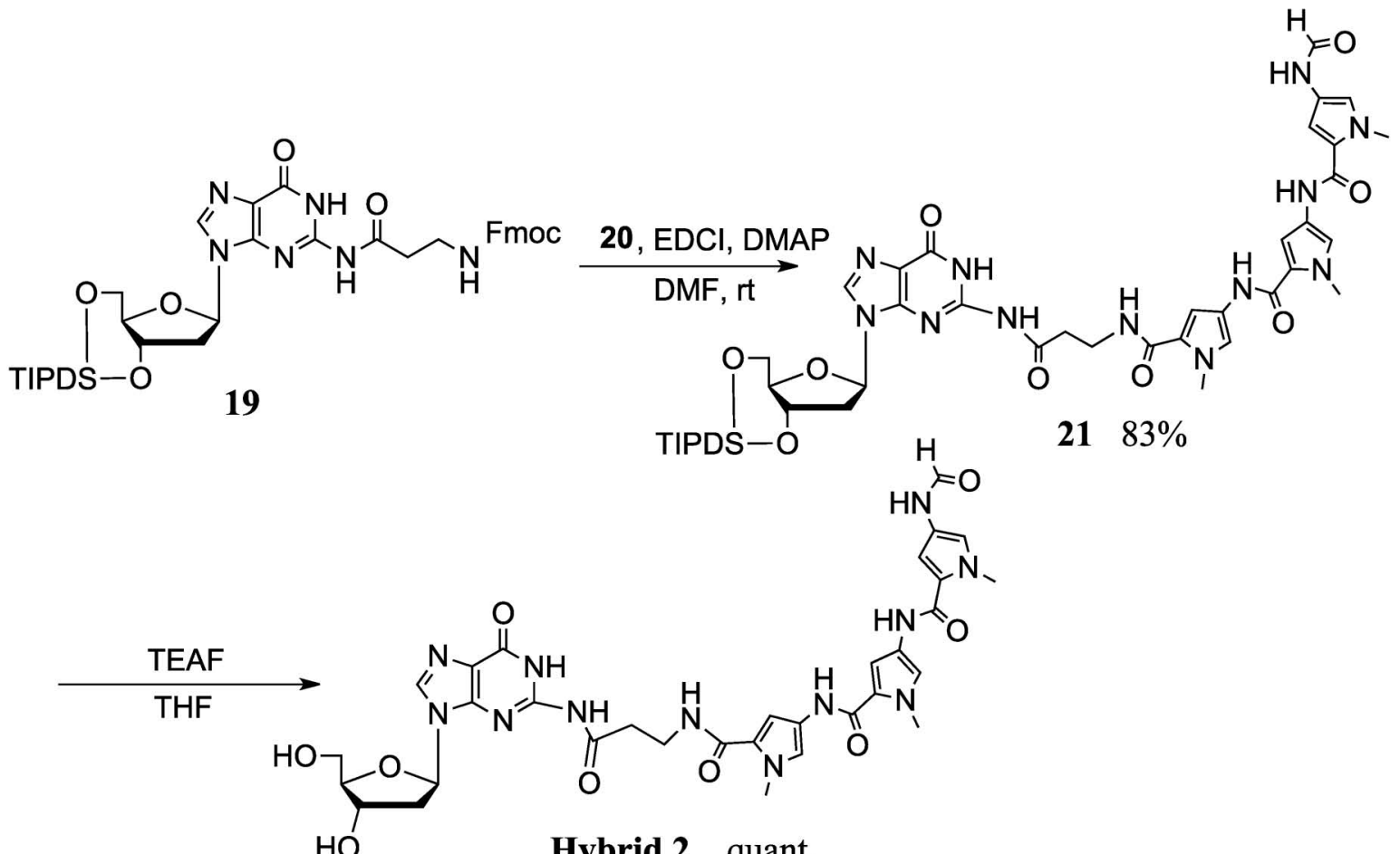

Hybrid 2 quant.

Scheme 8 .

ることができた。しかし，ここでピペリジンがわず かでも除去しきれずに残留してしまうと，20 とピ ペリジンとが縮合した副生物が生じてしまい，シリ カゲルカラムによる 21 の精製が困難であった。 そ こで，新たな脱保護試薬として反応活性点を持たな い第 3 アミンである 4-ジメチルアミノピリジン （DMAP）を用いることとし，Fmoc 基の除去とと もに縮合反応が進行すると考え，縮合反応条件下 DMAP を共存させて反応を行った。 その結果, 19 より収率 $83 \%$ で 21 を得ることができた。続いて 3'位及び $5^{\prime}$ 位を保護している TIPDS 基をフッ素化
テトラエチルアンモニウム (TEAF) により除去し, 目的とする Hybrid 2 の合成を達成した (Scheme 8).

1-2-4. ジアミノアルカンをリンカーとして用い たピロールポリアミド-2'-デオキシグアノシンハイ ブリッド（Hybrid 3）の合成Ｈybrid 2 ではグ アノシンの 2 位のアミノ基とリンカーの結合様式が, DNA 合成の際に保護基として一般に用いられるア ミド結合であり安定性に問題が残る。そこで安定に 存在できる結合様式として $2^{\prime}$-デオキシグアノシン の環外アミノ基に直接アルキル鎖を導入した Hybrid 3 を設計した. 
Hybrid 3 の合成は，様々なアミン類と $N 2$ 位で の置換反応が報告されている 3', 5'-ジ-O-アセチル2-フルオロ-O6-[2-(4-ニトロフェニル）エチル]-2'デオキシグアノシン $(\mathbf{2 6})^{36,37)}$ を反応中間体とし, この 26 と 1,3-ジアミノプロパンをリンカーとして 有する 25 とを結合させることを計画した.

グアノシン誘導体 26 を組み込んだオリゴヌクレ オチドは様々な機能性分子と結合したアミンと 26 のフルオロ基との置換反応により，修飾オリゴヌク レオチドを合成できることから，ポストシンセティ ック修飾法 ${ }^{37,38)}$ への適用も視野に入れ，この方法で の Hybrid 3 の合成を検討することとした，26 は Kamaike らの方法により 2'-デオキシグアノシンの $3^{\prime}$ 位及び $5^{\prime}$ 位アセチル化, $O^{6}$ 位の 2-(4-ニトロフェ ニル）エタノールによる保護の後， $45 \%$ フッ化水素 ピリジンと亜硝酸 $t$-ブチルで処理することで容易に 合成した. ${ }^{36}$

化合物 25 の合成にあたつては，20 と 1,3-ジアミ ノプロパンの縮合により合成できるものと考えられ るが，20は前述したように収率が低い。この低収 率は, 8 の Boc 基除去後の $N$-ホルミル化の際に力 ルボン酸が脱炭酸するものであった。そこで本合成 では， $N$ 末端を構築する前にあらかじめカルボン 酸部にリンカーを導入することで前述の問題点が解 決できるものと考えた.

まず，大過剩量の 1,3-ジアミノプロパンの DMF 溶液中に，カルボン酸 8 と EDCI，DMAP を溶解 した DMF 溶液を滴下にして縮合反応を行った。し かし主生成物として得られたものは 1,3-ジアミノプ ロパンの両末端がカルボン酸 8 と縮合した副生物で あった.

そこで，あらかじめ 1,3-ジアミノプロパンの一方 のアミノ基のみを選択的に保護する方法を検討し た。 アミノ基の保護基は，8 と一方を保護した 1,3ジアミノプロパンとの縮合後ピロールポリアミドの
$N$ 末端部の Boc 基の除去の際に安定であることが 必要であるため, この脱保護条件下で安定な Fmoc 基を選択した。

末端ジアミノアルカン化合物を選択的に片側だけ 保護する方法は，大過剩量のジアミンを用いる方法 が多くを占めるが，試薬を浪費する上，収率も好ま しいものではない，さらに Fmoc 基は塩基性条件下 で除去されるため，ジアミン化合物の 1 工程での mono-Fmoc 化はなされていない.

近年 Christensen らは Boc 基などの保護基を導入 する際にフェニルカルボネートを用いることで当量 の基質（ジアミノアルカンなど）に対して選択的に モノプロテクト化することに成功している (Scheme 9). ${ }^{39)}$

そこでこの方法を応用することでジアミノアルカ ンに対して mono-Fmoc 化を検討することとした.

まず mono-Fmoc 化試薬となる 9-フルオレニルメチ ルフェニル カーボナート（22）を Scheme 10 に示す方法にて合成した．続いて 1,3-ジアミノプロ パンと等量の 22 をメタノール中で反応させた後, 保護されていないアミンの求核攻撃による Fmoc 基 の脱落を防ぐため塩酸塩とすることで，好収率で 1,3-ジアミノプロパンの mono-Fmoc 体 23 の合成を 達成した（Scheme 10）。また，本合成はプトレシ ン (1,4-ジアミノブタン), カダベリン（1,5-ジアミ ノペンタン)に対しても適用できることを確認した.

次に，カルボン酸 $\mathbf{8}$ とアミン $\mathbf{2 3}$ の縮合法につい て検討した。今まで用いてきた EDCI/DMAP によ る縮合を行うと DMAP や EDCI 中のジメチルアミ ノプロピル基の塩基性により Fmoc 基が脱落してし まうことが明らかになった。そこで，縮合剤として $\mathrm{DCC} / \mathrm{HOBT}$ を用い，アミン塩酸塩 23 の酸のトラ ップには Fmoc 基にできるだけ影響を与えず塩酸塩 を補足できるジイソプロピルエチルアミン（DIEA） を用いたところカルボン酸 8 とアミン 23 の縮合体

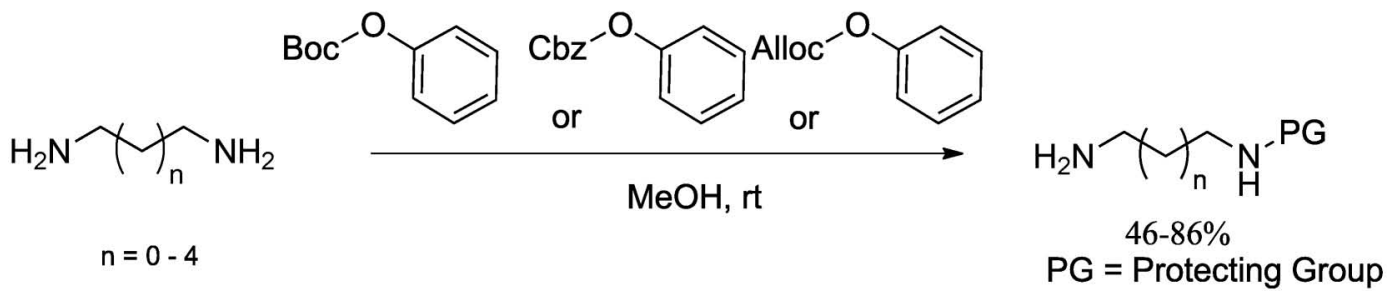

Scheme 9. 


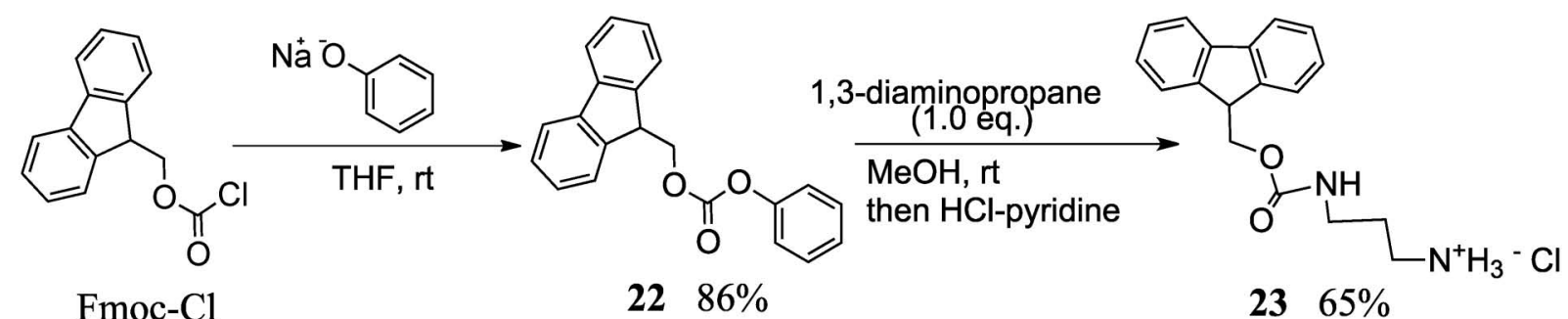

Scheme 10 .

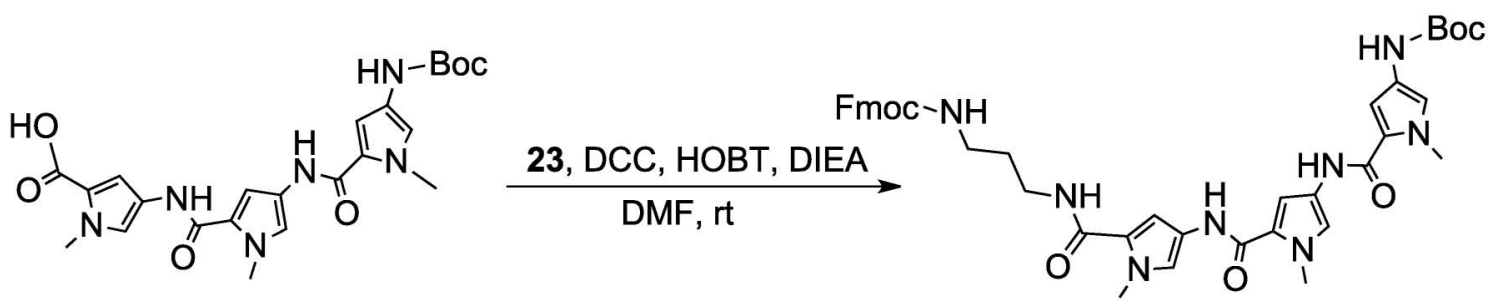

8

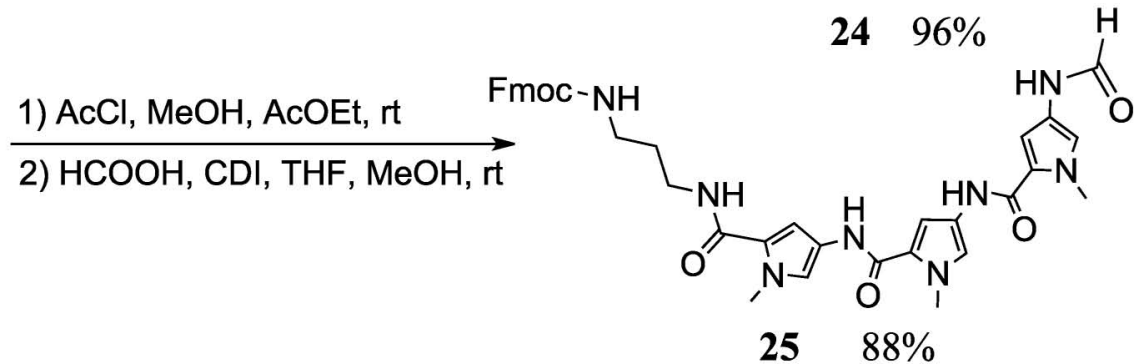

Scheme 11 .

24 を収率 $96 \%$ で合成することに成功した。続いて 酸性条件下 24 の Boc 基を除去した後，カルボン酸 10 の合成と同条件でホルミル化を行うことで，収 率 $88 \%$ と効率よく 25 の合成を達成した（Scheme 11).

次に 25 と 2'-デオキシ-2-フルオロイノシン誘導 体 26 の縮合を試みた。まず 25 の Fmoc 基の除去に 第 3 アミンを用いることで，シリカゲルカラムによ る精製を容易にすることも考慮し，減圧濃縮により 除去できるトリエチルアミンを用いた反応を試み た．その結果，Fmoc 基の除去及び縮合反応が効率 よく進行し，副反応を伴うことなく $2^{\prime}$-デオキシグ アノシン誘導体 27 を 25 より $81 \%$ の収率で得るこ とができた

最後に 27 の $O^{6}$ 位 2-(4-ニトロフェニル) エチル 基及び 3'位並びに $5^{\prime}$ 位アセチル基を除去すること で，直鎖ジアミノアルキルをリンカーとして用いた Hybrid 3 の合成を達成した（Scheme 12）。

1-3. ピロールポリアミドーヌクレオシドハイブ リッド化合物の dsDNA に対する塩基配列選択能の
評価上述した合成ハイブリッド化合物の DNA との相互作用を検討するために，ハイブリッド化合 物とディスタマイシン A の二重鎖 DNA（dsDNA） に対する塩基配列選択能を比較し評価した（コンセ プト A).

解析方法としては，MGB ポリアミドの DNA と の相互作用の検討に汎用されている $T_{\mathrm{m}}$ 值の測定及 び CD（円二色性）スペクトル解析により行うこと とした. ${ }^{40-43)}$

$T_{\mathrm{m}}$ 值測定の検出器としては示差走査熱量計 (DSC) やUV 吸収を利用する方法が知られている が，検体の使用量が少量で済むことや測定の簡便性 を考慮し核酸分子の UV $(260 \mathrm{~nm})$ 吸収を用いた $T_{\mathrm{m}}$ 值の測定を行つた。

$\mathrm{CD}$ スペクトル解析は低分子中の不斉炭素検出の ほかに，タンパク質やDNA，RNA などの高分子 化合物において高次構造の決定に補足的に利用でき る。また溶液の状態で測定するため生体内条件を再 現でき, 液相条件の変化に伴う三次元構造の変化を 敏感に検出できるといった利点がある. ${ }^{44)}$ 

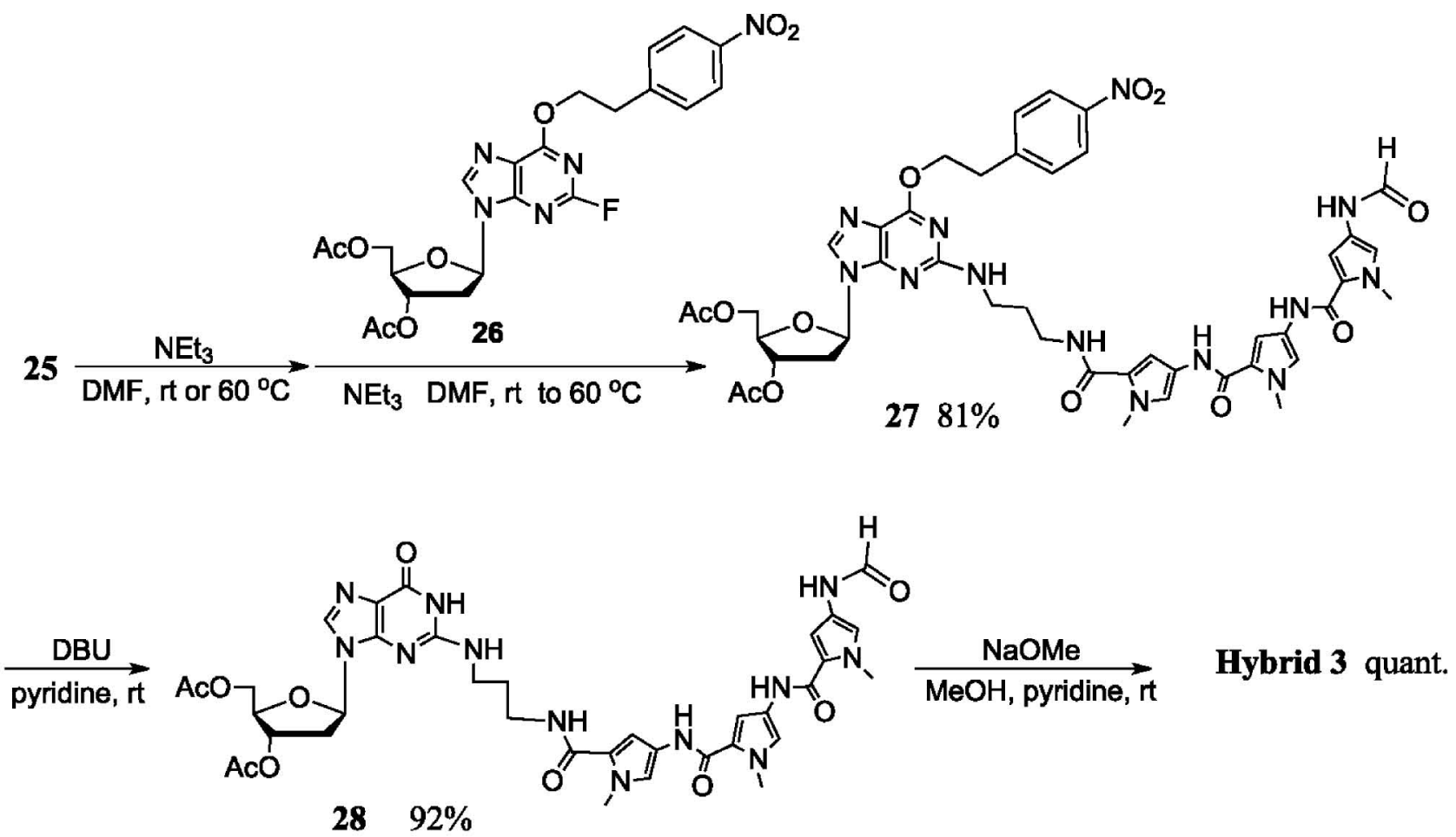

Scheme 12 .

本来ディスタマイシン A はアキラルな分子であ り，溶液中単体で円二色性を示すことはない。 ${ }^{41)} し$ かし，そこに dsDNA を共存させると DNA 自体の 示す CD スペクトル (220-300 nm) とは異なる波 長領域（300-360 nm）に新たな CD スペクトルが 誘起される (ICD signals: Induced Circular Dichroism signals). ${ }^{43)}$ この ICD は，ディスタマイシン A 中の発色団が副溝中の塩基と水素結合によりキラリ ティーを持つことに起因し，ICD の大きさはディ スタマイシン $\mathrm{A}$ 中の $\pi-\pi$ 遷移を示している. ${ }^{45)}$ Wemmer らはこの ICD を用いてディスタマイシン A とdsDNA が 2:1 で結合していることを裏付け ており,40)ほかにも ICD を用いることで様々な MGB ポリアミドー機能性分子ハイブリッド化合物 が dsDNA 中に配位していることが証明されてい る. ${ }^{40-43,45)}$

dsDNA としては，ピロールポリアミドのマッチ

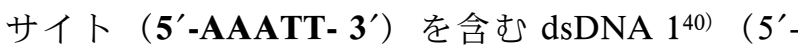
CGCAAATTGGC- $3{ }^{\prime} / 3^{\prime}$-GCGTTTAACCG- 5'), dsDNA 1 のマッチサイト内に 2 つの G-C 塩基対を 含む dsDNA 2 (5'-CGCAGACTGGC- $3^{\prime} / 3^{\prime}$-GCGTCTGACCG- 5')，マッチサイトを含まず 4 塩基が ランダムに配列した dsDNA 3（5'-GCACGACTA-
CG- 3'/3' -CGTAGTCGTGC- 5') を選択し，Wemmer らの方法40)を参考に測定を行った.

1-3-1. UV 吸収を用いた $T_{\mathrm{m}}$ 值測定による塩基配 列選択能の評価 異なる配列を持つ dsDNAに対 して，リガンドとして Hybrid 1, Hybrid 2, Hybrid 3 及び比較対象化合物としてディスタマイシン A を，それぞれ当量を変えて作用させ， dsDNA の $T_{\mathrm{m}}$ 值の相違から各配列に対する選択性の評価を行った.

この結果，ディスタマイシン A からは既報のと おり dsDNA1 に対して特に高い親和性を持ってい ることが確認された。一方 Hybrid 1, Hybrid 2 及 び Hybrid 3 はマッチサイトを含む dsDNA1 に対し てのみ二重鎖の安定化作用を示したが， dsDNA 2, dsDNA 3 に与える影響はほとんど観測されず，デ イスタマイシン A の配列選択能と比較して優れた 配列選択能を有することが明らかになった（Table $1)$.

しかしながら，これらハイブリッド化合物の dsDNA に対する親和性に関してはディスタマイシ ン $\mathrm{A}$ の示す $\Delta T_{\mathrm{m}}$ 值（ディスタマイシン $\mathrm{A}: \mathrm{dsD}-$ $\mathrm{NA} 1=2: 1$ のとき $\left.22.9^{\circ} \mathrm{C}\right)$ と比較して大幅に低下 した. (Hybrid 1 : dsDNA 1=2: 1 のとき $2.3^{\circ} \mathrm{C}$, Hybrid 2 : dsDNA $1=2: 1$ のとき $3.8^{\circ} \mathrm{C}$, Hybrid 
Table 1. $\Delta T_{\mathrm{m}}$ Values $\left({ }^{\circ} \mathrm{C}\right)$ for the DNA Duplexs with Ligand

\begin{tabular}{l|c|r|r|r}
\hline \hline & Ligand : dsDNA & $1: 1$ & $2: 1$ & $3: 1$ \\
\hline Hybrid 1 & dsDNA 1 & 2.1 & 2.3 & 1.9 \\
\hline & dsDNA 2 & -0.1 & 0.2 & 0.1 \\
\hline Hybrid 2 & dsDNA 3 & -0.4 & 0.3 & -0.3 \\
\hline & dsDNA 1 & 2.7 & 3.8 & 3.9 \\
\hline & dsDNA 2 & -0.3 & -0.2 & -0.1 \\
\hline Hybrid 3 & dsDNA 3 & 0.2 & 0.3 & 0.3 \\
\hline & dsDNA 1 & 5.6 & 5.7 & 5.8 \\
\hline & dsDNA 2 & 0.1 & 0.2 & 0.4 \\
\hline Dstamycin A & dsDNA 1 & 22.9 & 22.9 & 23.5 \\
\hline & dsDNA 2 & 3.0 & 6.5 & 6.9 \\
\hline & dsDNA 3 & 15.2 & 16.3 & 16.3 \\
\hline
\end{tabular}

(Hybrid 1, Hybrid 2, Hybrid 3, or Distamycin A) at several [ligand]/ [duplex] ratios in buffer consisting of $10 \mathrm{~mm}$ sodium phosphate, $10 \mathrm{~mm}$ $\mathrm{NaCl}$, and $0.1 \mathrm{mM} \mathrm{Na}_{2}$ EDTA at $\mathrm{pH}$ 7.0. $\Delta T_{\mathrm{m}}$ value $=\left(T_{\mathrm{m}}\right.$ value in the presence of a ligand $)-\left(T_{\mathrm{m}}\right.$ value in the absence of a ligand $) . T_{\mathrm{m}}$ values for DNA duplexs in the absence of a ligand:

DNA $1=\mathrm{d}-\left(5^{\prime}\right.$-CGCAAATTGGC-3') $-\mathrm{d}-\left(3^{\prime}-\right.$ GCGTTTAACCG-5')

$T_{\mathrm{m}}=32.2^{\circ} \mathrm{C}$

DNA $2=\mathrm{d}-\left(5^{\prime}-\mathrm{CGCAGACTGGC}-3^{\prime}\right)-\mathrm{d}-\left(3^{\prime}-\mathrm{GCGTCTGACCG}-5^{\prime}\right)$ $T_{\mathrm{m}}=39.5^{\circ} \mathrm{C}$

DNA $3=\mathrm{d}-\left(5^{\prime}-\right.$ GCACGACTACG-3') $-\mathrm{d}-\left(3^{\prime}-\mathrm{CGTGCTGATGC-5^{ \prime } )}\right.$ $T_{\mathrm{m}}=33.9^{\circ} \mathrm{C}$

$3:$ dsDNA $1=2: 1$ のとき $\left.5.7^{\circ} \mathrm{C}\right)$ 。これら選択能の 向上及び親和性の低下は, これらリガンド（Hybrid

1, Hybrid 2, Hybrid 3 及びディスタマイシン A) の構造中の陽イオン電荷の有無によるものと考えら れる。

DNA 骨格中には陰イオン性のリン酸基が存在 し，陽電荷を持つ化合物（ポリアミンなど）と塩基 配列に関係なくイオン結合を形成することが知られ ている. ${ }^{46)}$ ディスタマイシン A はアミジン残基の 陽電荷によりイオン結合による高い親和性を示す が，このためにピロールポリアミド部位の塩基配列 選択能が顕著に発揮されないことが推測できる。一

方，Hybrid 1, Hybrid 2 及び Hybrid 3 は陽電荷を 有しておらず MGB ポリアミド部位本来の塩基配列 選択能があらわれた結果, $\Delta T_{\mathrm{m}}$ 值は低いものの優 れた塩基配列を選択的に認識し二重鎖安定化作用を 示したものと考察した.

1-3-2. ICD スペクトルを用いた塩基配列選択能 の評価ＣD スペクトルからは，MGB ポリアミ ドが dsDNA に結合した際に誘起される CD バンド
（ICD：300-360 nm）を利用することでこれらの相

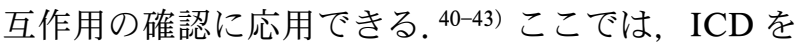
観測することで dsDNA に対するハイブリッド化合 物中のピロールポリアミドの作用を確認した.

dsDNA は， $T_{\mathrm{m}}$ 測定と同様の配列を用いリガンド として Hybrid 1, Hybrid 2, Hybrid 3 及び比較対象 化合物としてディスタマイシン $\mathrm{A}$ を用い, 測定条 件は $T_{\mathrm{m}}$ 測定と同様に Wemmer らの方法を参考に し, ${ }^{40)}$ 各 dsDNA に対してリガンドを 12 回に分け て 3 当量まで加え $\mathrm{CD}$ スペクトルに及ぼす影響を観 測した。それぞれの CD スペクトルを以下に示す (Fig. 7).

dsDNA 1 については，すべてのリガンドの濃度 上昇に伴い $330 \mathrm{~nm}$ 近辺に ICD がはっきりと確認 できる.このことから，ハイブリッド化合物のピ ロールポリアミド部位は dsDNA の副溝に配位する 機能を維持していることが明らかとなった。また Hybrid 2 やディスタマイシン A ではマッチサイト を持たないdsDNA 2 や dsDNA 3 に対しても ICD が観察されたが，Hybrid 1 及び Hybrid 3 ではわず かに CD バンドが誘起されるだけであった。 $T_{\mathrm{m}}$ 值 の測定を考慮すると ICD の有無が直接二重鎖の安 定化に相関があるとは言えないが，Hybrid 1 及び Hybrid 3 は Hybrid 2 やディスタマイシン A と比較 してより厳密な塩基配列選択能を有していると推測 できる

2. ピロールポリアミド-2'-デオキシグアノシン ハイブリッド化合物を組み込んだ ssDNA（Modified ssDNA）の合成と相補鎖 ssDNA に対する選択 的相互作用の評価 ${ }^{47)}$

2-1. ピロールポリアミド-2'-デオキシグアノシ ンハイブリッド化合物を組み込んだ ssDNA の設計 修飾ヌクレオシドには，例えば，AZT，DDIや d4T といった抗 HIV 薬などのように生合成により DNA 合成に利用され様々な薬理活性を持つものが 知られている。同様に，ピロールポリアミドハイブ リッド化合物は，生合成により DNA 鎖に取り込ま れた際に MGB ポリアミドのマッチサイトを含む dsDNA の二重鎖安定化効果を発揮することが期待 され，特定遺伝子の発現制御につながるものと考え られる（コンセプト B).

合成したハイブリッドの中で, 上述した $\Delta T_{\mathrm{m}}$ 值 や ICD から Hybrid 3 が 2 本鎖 DNA の安定化効果 


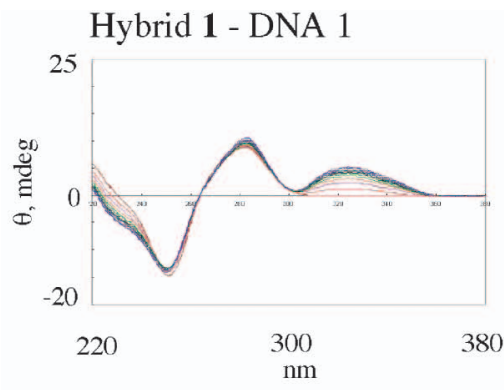

Hybrid 2 - DNA 1

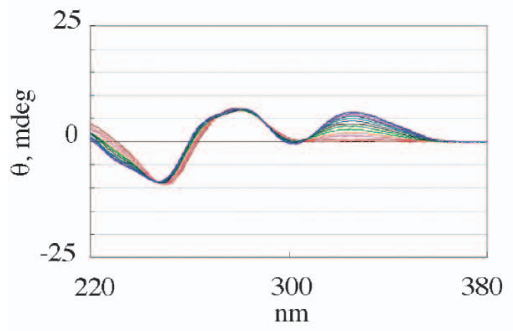

Hybrid 3 - DNA 1

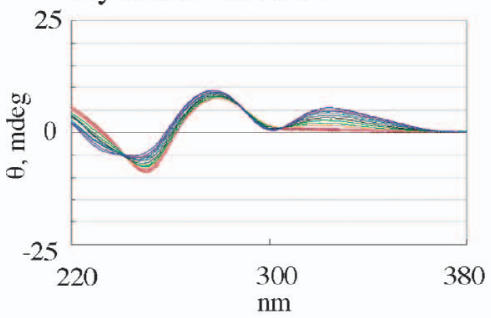

Dst - DNA 1

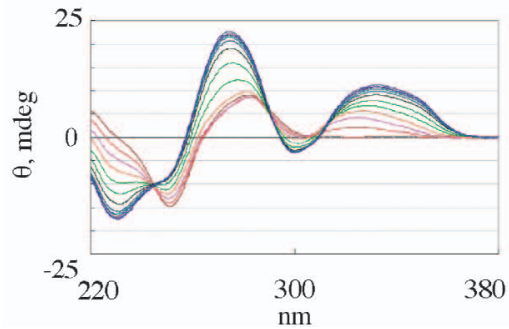

Hybrid 1 - DNA 2

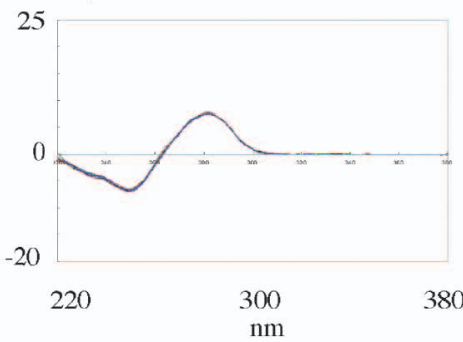

Hybrid 2 - DNA 2

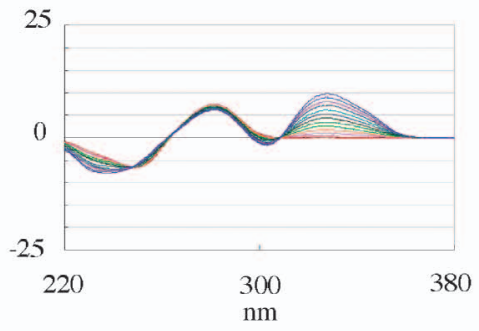

Hybrid 3 - DNA 2

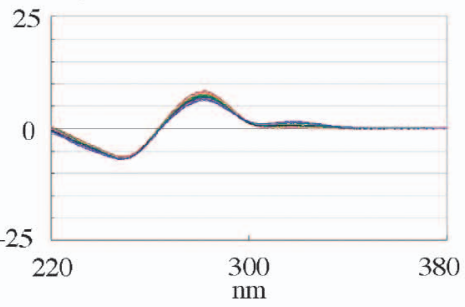

Dst - DNA 2

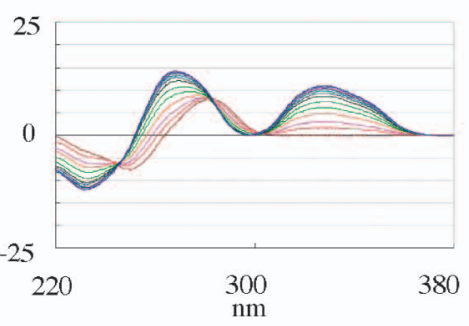

Hybrid 1 - DNA 3

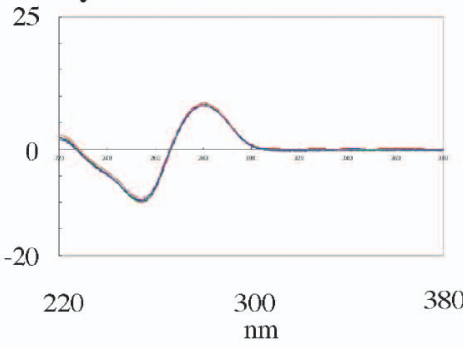

Hybrid 2 - DNA 3

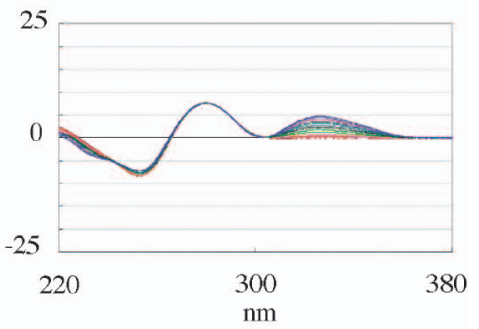

Hybrid 3 - DNA 3

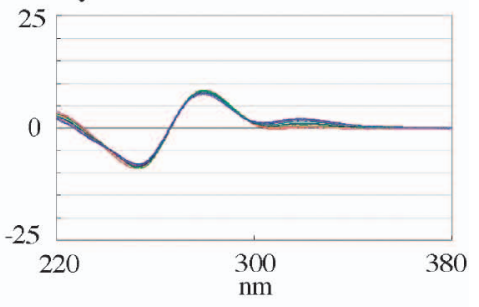

Dst - DNA 3

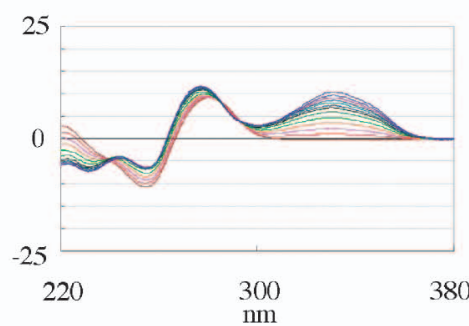

Fig. 7. CD Spectra for the DNA Duplexs with Ligand

(Hybrid 1, Hybrid 2, Hybrid 3, or Distamycin A) at several [ligand] / [duplex] ratios in buffer consisting of $10 \mathrm{~mm}$ sodium phosphate, $10 \mathrm{~mm} \mathrm{NaCl}$, and 0.1 $\mathrm{mm} \mathrm{Na}{ }_{2} \mathrm{EDTA}$ at $\mathrm{pH} 7.0$ and $20^{\circ} \mathrm{C}: 3.0 \mathrm{ml}$ of duplex solution $(5.8 \mu \mathrm{M})$ titrated ligand (Hybrid 2, Hybrid 3, and Dst: $\left.0-14.5 \mu \mathrm{M}\right)$ and $3.0 \mathrm{ml}$ of duplex solution $(4$ $\mu \mathrm{M})$ titrated ligand (Hybrid 1: $0-12 \mu \mathrm{M})$.

DNA duplexs: DNA $1=\mathrm{d}-\left(5^{\prime}\right.$-CGCAAATTGGC-3') $-\mathrm{d}-\left(3^{\prime}-\mathrm{GCGTTTAACCG}-5^{\prime}\right)$

DNA $2=\mathrm{d}-\left(5^{\prime}-\right.$ CGCAGACTGGC- $\left.3^{\prime}\right)-\mathrm{d}-\left(3^{\prime}-\right.$ GCGTCTGACCG- $\left.5^{\prime}\right)$

DNA $3=\mathrm{d}-\left(5^{\prime}-\mathrm{GCAC} \overline{\mathrm{G}} \mathrm{A} \overline{\mathrm{C}} \mathrm{TACG}-3^{\prime}\right)-\mathrm{d}-\left(3^{\prime}-\mathrm{CGTG} \overline{\mathrm{CT}} \overline{\mathrm{G}} \mathrm{ATGC}-5^{\prime}\right)$

が高いことからオリゴマーに組込みその活性を検討 することとした。しかし，Hybrid 3 を DNA 合成 の脱保護条件である $25 \%$ アンモニアで処理したと ころ，N- 末端のホルミル基が脱落したと思われる 化合物が得られ，Hybrid 3 を組み込んだ DNA を 合成するのは困難であることが予想された。

Hybrid 3 をアンモニア処理した際にピロール間の アミド結合はアミドの $\pi$ 結合がピロール環との共
鳴により安定化していることから，アンモニア処理 に対して安定なハイブリッド化合物として，N末 端に 1-メチルピロール-2-カルボニル基をアミド結 合により結合させた Hybrid 4 を設計した (Fig. 8).

2-2. ピロールポリアミド-2'-デオキシグアノシ ンハイブリッド化合物を組み込んだ ssDNA の合成

2-2-1. ピロールアミド 4 量体-2'-デオキシグアノ シンハイブリッド（Hybrid 4) の合成＼cjkstart化合物 2 
<smiles>Cn1cccc1C(=O)C(Cl)(Cl)Cl</smiles>

2

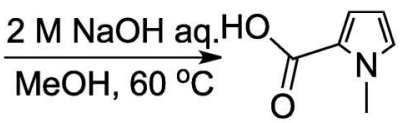

$2989 \%$<smiles>COC(=O)c1cc(NC(=O)c2cc(NC(=O)c3cc(NC(C)(C)C)cn3C)cn2C)cn1C</smiles>

7

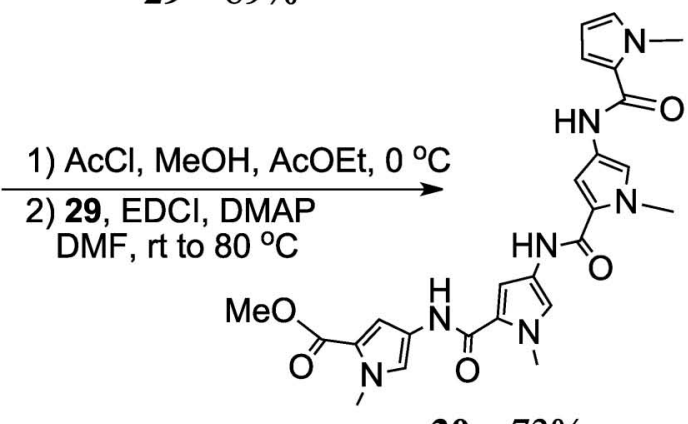

$3073 \%$

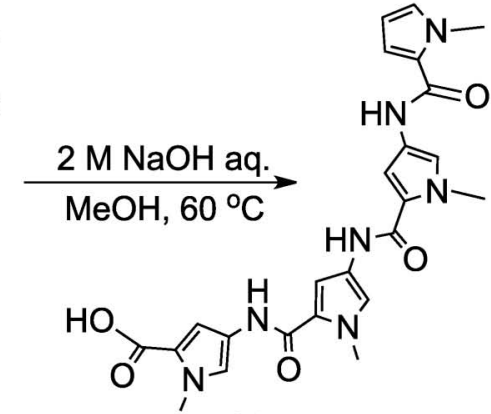

31 quant.

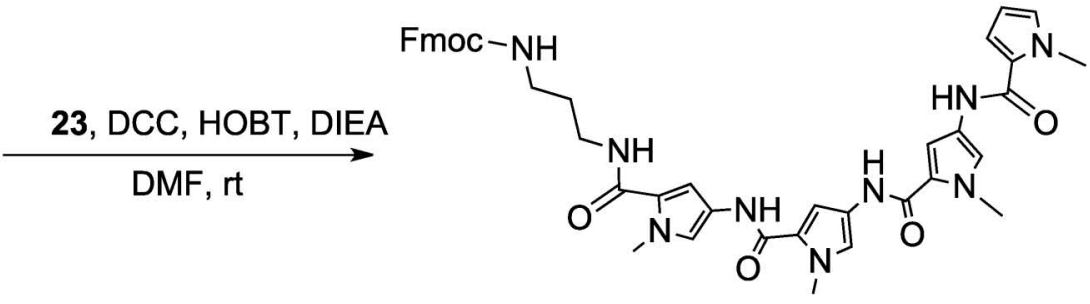

$3286 \%$

Scheme 13 .

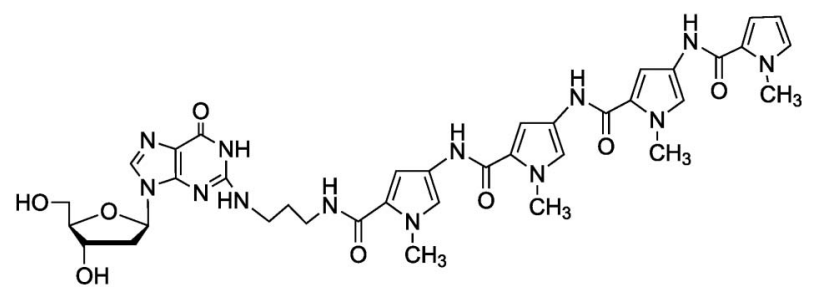

Fig. 8. Structure of Hybrid 4

をカルボン酸 29 へと変換し，これとピロールアミ ド 3 量体 7 から Boc 基を除去した化合物と縮合さ せることによりピロールアミド 4 量体 $\mathbf{3 0}$ を得た. 化合物 30 のエステル部を加水分解した後, monoFmoc ジアミノプロパン $\mathbf{2 3}$ と縮合させることで $\mathbf{3 2}$ を得た (Scheme 13).

続いて，32 の Fmoc 基をトリエチルアミンにて 除去し 2'-デオキ-2-フルオロシイノシン誘導体 26 のフッ素との置換反応を行うことで塩基部の変換を 伴い $2^{\prime}$-デオキシグアノシンにピロールアミド 4 量 体がリンクした 33 を得た。最後に 33 の $O^{6}$ 位 2- (4ニトロフェニル）エチル基及び $3^{\prime}$ 位と $5^{\prime}$ 位アセチル 基を除去することで Hybrid 4 を合成した（Scheme 14).
2-3. Hybrid 4 を組込んだ種々の一本鎖 DNA （Modified ssDNA）の合成まず Hybrid 4 のオ リゴマー合成におけるアンモニア処理の条件下での 安定性の評価を行ったところ安定に存在することが 確認された。そこで, DNA 合成条件下で安定な化 合物としてデザインしたハイブリッド化合物 （Hybrid 4）を組込んだ種々の一本鎖 DNA（Modified ssDNA）を合成し（Fig. 9)，その相補鎖 ssDNA との二重鎖 DNA の熱力学的安定性及び塩基配 列選択能の評価を $T_{\mathrm{m}}$ の比較することで, DNA 鎖 に取り込まれたピロールポリアミドの二重鎖安定化 作用の配列選択能を調べた. ${ }^{48)}$

Hybrid 4 で修飾した 4 種類のオリゴヌクレオチ ド (modified ssDNA) は, Hybrid 4 の 5 '位の $\mathrm{DMTr}$ 化後, $3^{\prime}$ 位のホスフィチル化して得たホスホ ロアミダイト 34 を用いた固相合成法により合成し た. ${ }^{49)}$ 常法では，ホスホロアミダイト 34 の立体障 害によるものか，縮合反応がほとんど進行しなかっ た.

そこで，反応条件を種々検討し，活性化剂 $(0.5$ M $1 H$-テトラゾール/アセトニトリル溶液）を 1.5 倍，反応時間を 20 分間にした結果，縮合収率を 40 


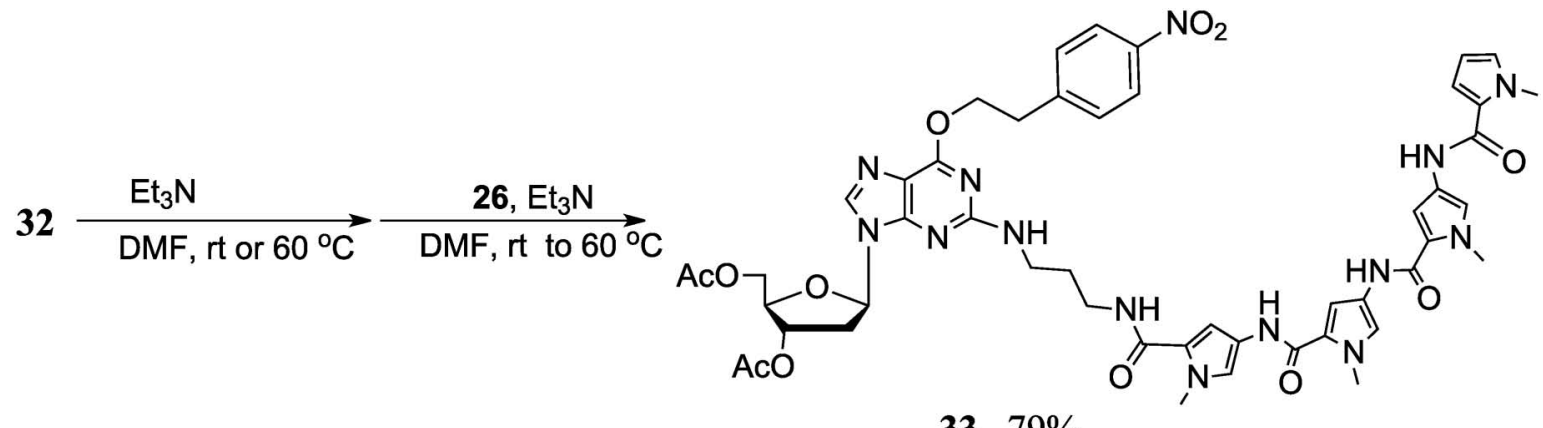

$3379 \%$

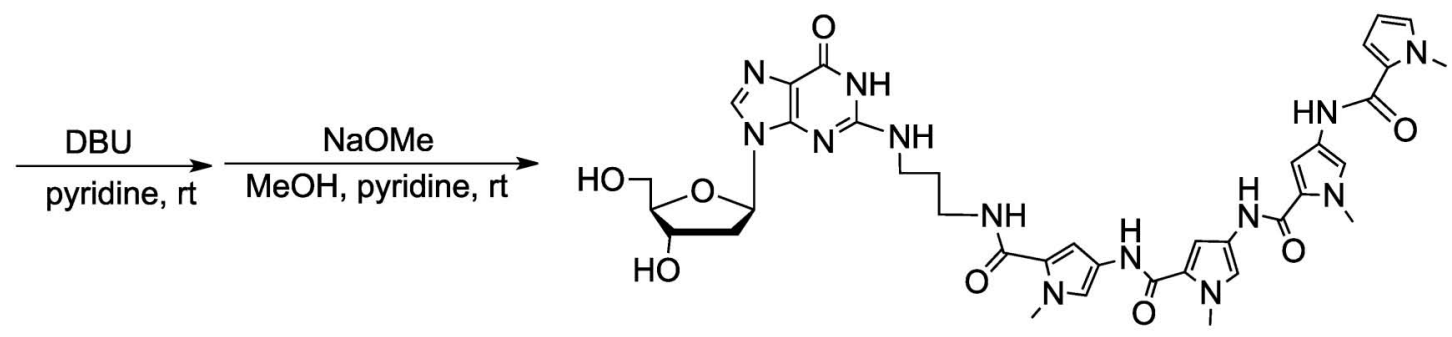

Hybrid 4 78\% (from 33)

Scheme 14

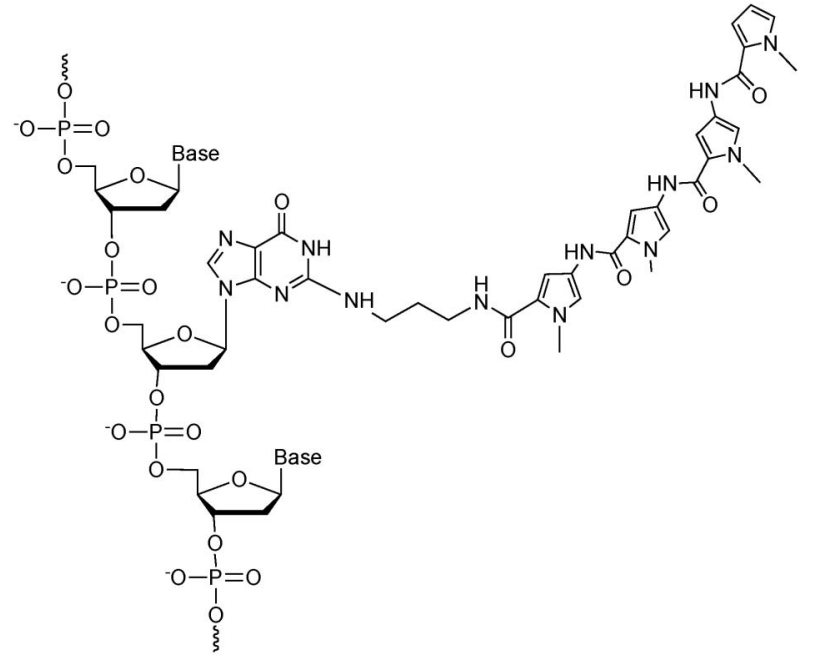

Fig. 9. Oligonucleotide Conjugated Hybrid 4 (Modified ssDNA)

-50\%とすることができ，修飾オリゴヌクレオチド を $1 \mu \mathrm{mol}$ スケールで約 $2 \mathrm{~A}_{260}$ units の収量で得るこ とができた (Scheme 15). 50)

目的オリゴマーは得ることができたものの，その 合成効率に問題点を残している。 そこで，2-フルオ ロ-2'-デオキシイノシン 3'-ホスホロアミダイト 36 （B＝IF，NPE） を用い2-フルオロ-2'-デオキシイノ シンを含んだオリゴヌクレオチド鎖を構築した後,
アミノアルキルリンカーを含むピロールアミド 4 量 体を処理し，塩基部 2 位のフルオロ基と置換するポ ストシンセッティック法による修飾オリゴヌクレオ チド（modified ssDNA）の合成を試みた（Scheme 16）.38）常法に従い，2-フルオロ-2'-デオキシイノシ ンを組达んだオリゴヌクレオチドを $\mathrm{CPG}$ 担体上で 構築した後, トリエチルアミンの存在下 32 を処理 した. 化合物 32 の Fmoc 基の除去と, 続く 2-フル オロ $-2^{\prime}$-デオキシイノシン塩基部 2 位での置換反応 を $\mathrm{CPG}$ 担体上でも起こさせることができ，修飾才 リゴヌクレオチド $\left[5^{\prime}-\mathrm{d}\right.$ (CGXAATTTGGC) -3' : $\mathbf{X}=$ Hybrid 4] $0.25 \mu \mathrm{mol}$ スケールで $10.2 \mathrm{~A}_{260}$ units の収量で得ることができた. ${ }^{50)}$

2-4. Hybrid 4 を組込んだ ssDNA（Modified SsDNA）類の遺伝情報制御分子としての評価

Hybrid 4 で修飾した 4 種類のオリゴヌクレオチ ド (modified ssDNA) I-IV (11-mer) (Fig. 10) と その相補鎖からなる modified dsDNA 及び未修飾 dsDNA の融解温度（ $T_{\mathrm{m}}$ 值）を測定し，それぞれの $T_{\mathrm{m}}$ 值の差（ $\Delta T_{\mathrm{m}}$ 值）を比較することで，二重鎖安 定化作用の配列特異性について調べた（Table 2). ${ }^{48)}$ その結果, ピロールポリアミドのマッチサイト（5'AATTT-3' $/ 3^{\prime}$-TTAAA-5') を含む modified dsDNA 


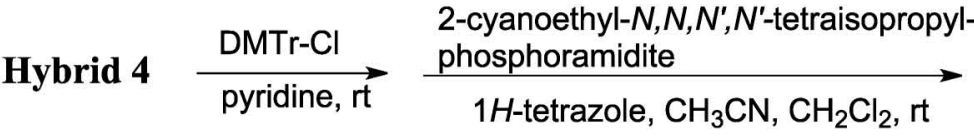

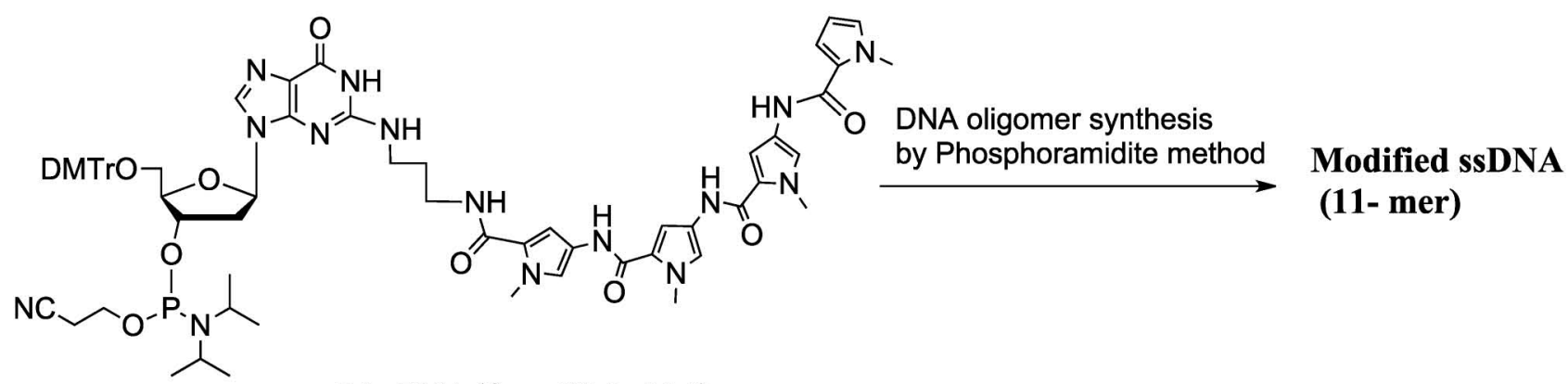

$3471 \%$ (from Hybrid 4)

Scheme 15.

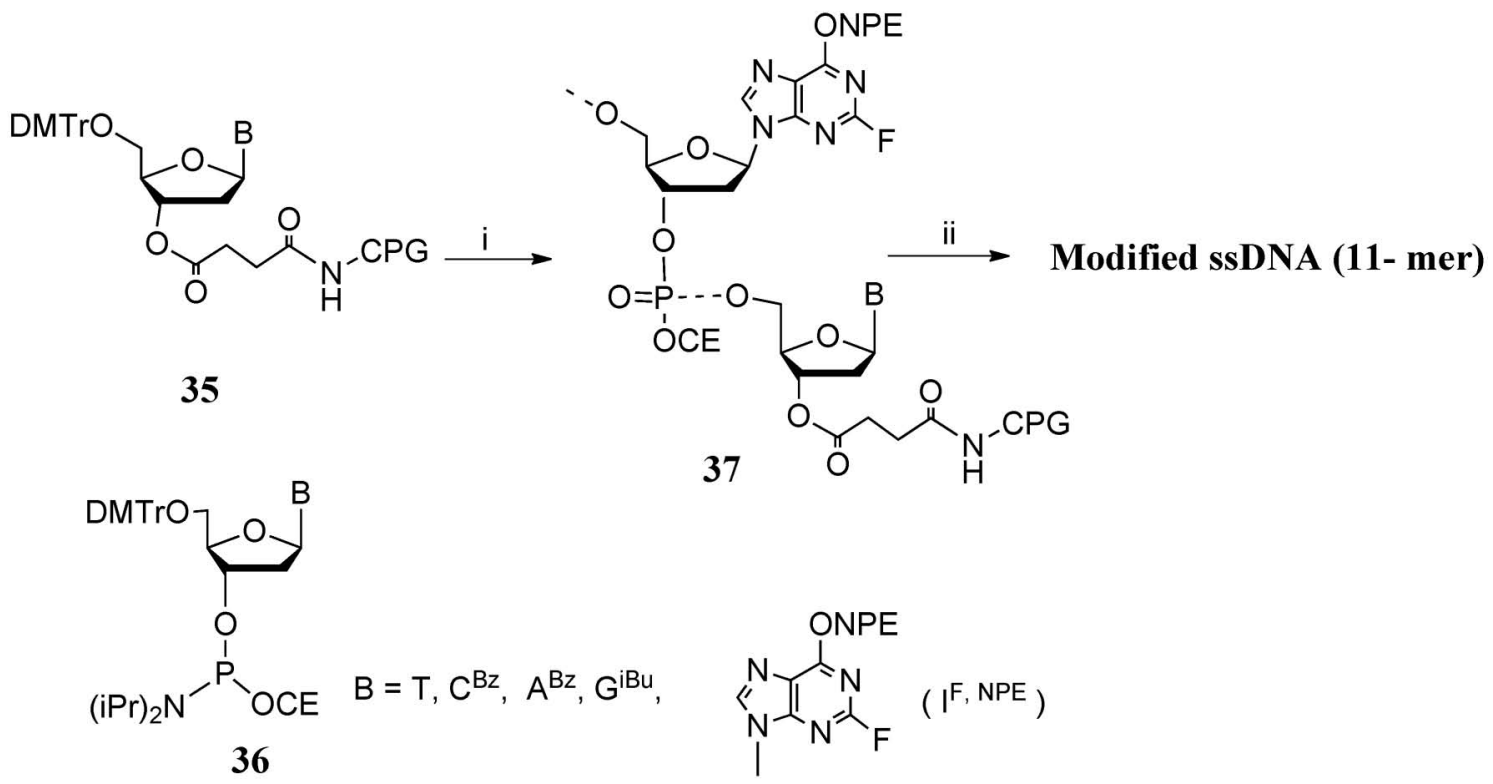

Scheme 16 .

Reaction conditions i) Oligonucleotide assembly on CPG support by the phosphoramidite method, ii) $1.0 .05 \mathrm{M} \mathrm{32,1}: 5 \mathrm{Et}{ }_{3} \mathrm{~N} / 1,4-\mathrm{dioxane}, 60^{\circ} \mathrm{C}, 24 \mathrm{~h} ; 2.0 .5 \mathrm{M}$ DBU, pyridine, rt., $12 \mathrm{~h} ; 3$. conc. $\mathrm{NH}_{4} \mathrm{OH}, \mathrm{rt}, 3 \mathrm{~h}-55^{\circ} \mathrm{C}, 6 \mathrm{~h}$.

I は，未修飾 dsDNA と比較して $T_{\mathrm{m}}$ 值が $23^{\circ} \mathrm{C}$ 上昇 した。この安定化は, 前述した dsDNA [5'-d (CGCAAATTGGC) -3', 3'-d (GCGTTTAACCG) -5'] への Hybrid 3 の添加による二重鎖の安定化 $\left(\Delta T_{\mathrm{m}}\right.$ 值 $\left.5.6^{\circ} \mathrm{C}\right)$ と比較して，かなり大きなもので あった.

ピロールポリアミドのマッチサイト部の A-T 塩 基対の一塩基を G-C 塩基対に変えた modified dsDNA II 及び modified dsDNA III は, modified dsDNA I の二重鎖の安定性に比べ約 $6^{\circ} \mathrm{C}$ 程低下したも のであった。ささらに、ピロールポリアミドのマッチ
サイト部の A-T 塩基対の二塩基を $\mathrm{G}-\mathrm{C}$ 塩基対に変 えた modified dsDNA IV は，ピロールポリアミド 部による二重鎖の安定化はみられず，ピロールポリ アミド部の立体反発によるものと推測される $3.2^{\circ} \mathrm{C}$ の不安定化を引き起こし，ピロールポリアミド部の 配列識別能を示す結果を得た。また, modified dsDNA I の CD スペクトルは, B-型 DNA のコンホ メーションを示し (Fig. 7, ligand $=0 \mu \mathrm{M})$, さらに, MGB ポリアミドが dsDNA の副溝に結合した際に 誘起される特徵的な CD バンド $(300-360 \mathrm{~nm})^{40)}$ が みられた。これは，二重鎖の副溝に位置するグアニ 


\section{dsDNA I 5'-d(GCCAAATTCCG)-3' 3'-d(CGGTTTAAXGC)-5' \\ dsDNA II 5'-d(GCCAAAGTCCG)-3' 3'-d(CGGTTTCAXGC)-5' \\ dsDNA III 5'-d(GCCAGATTCCG)-3' 3'-d(CGGTCTAAXGC)-5' \\ dsDNA IV 5'-d(GCCAGACTCCG)-3' 3'-d(CGGTCTGAXGC)-5' \\ modified dsDNA : $\mathbf{X}=$ Hybird 4 control dsDNA : $X=d G$}

Fig. 10. Modified dsDNAs

Table 2. $T_{\mathrm{m}}$ Values of Modified dsDNA and Unmodified dsDNA and $\Delta T_{\mathrm{m}}$ Values

\begin{tabular}{c|c|c|c}
\hline \hline Entry & dsDNA & $T_{\mathrm{m}}\left({ }^{\circ} \mathrm{C}\right)$ & $\Delta T_{\mathrm{m}}\left({ }^{\circ} \mathrm{C}\right)$ \\
\hline 1 & modified dsDNA I & 55.4 & 23.0 \\
2 & non-modified dsDNA I & 32.4 & \\
\hline 3 & modified dsDNA II & 53.4 & 17.4 \\
4 & non-modified dsDNA II & 36.0 & \\
\hline 5 & modified dsDNA III & 52.4 & 16.7 \\
6 & non-modified dsDNA III & 35.7 & \\
\hline 7 & modified dsDNA IV & 35.4 & -3.2 \\
8 & non-modified dsDNA IV & 38.6 & \\
\hline
\end{tabular}

$\Delta T_{\mathrm{m}}\left({ }^{\circ} \mathrm{C}\right)=T_{\mathrm{m}}($ modified dsDNA $)-T_{\mathrm{m}}$ (non-modified dsDNA).

ン塩基部 2 位に導入されたピロールアミド 4 量体の 二重鎖安定効果を示すものである.

以上の結果は, 生合成過程において遺伝子に Hybrid 4 が取り込まれた場合, マッチサイトの配 列を有する二重鎖においてその二重鎖を安定化し， 遺伝子の複製や転写を抑制することが期待されるも のであった.

前述の modified ssDNA の相補鎖との二重鎖の安 定化能は, modified ssDNA のアンチセンス治療薬 として可能性を示すものである（コンセプトC).

Zamecnik らは, 効果的なアンチセンス治療薬の開 発を目的として，B 型二重鎖 DNA の A-T 塩基対 が連なつた配列のマイナーグルーブに結合する抗生 物質のネトロプシンやディスタマイシン A を DNA オリゴヌクレオチドの $3^{\prime}$ 及び $5^{\prime}$ 末端に結合させた
コンジュゲート体を合成し，コンジュゲート体を含 む二重鎖 DNA の安定性を調べている. ${ }^{51)}$ その結 果，コンジュゲート体は，その二重鎖 DNA の安定 性を高めることを報告している。 Derven らは, MGB のヘアピン型ヘテロ 2 量体を DNA オリゴヌ クレオチドの 5'未端に結合させたコンジュゲート 体を合成し，二本鎖 DNA を標的としたアンチジー ン医療への応用を検討しており，コンジュゲート体 が標的二本鎖 DNA を主溝と副溝の両方から認識 し，配列特異的に高い親和性で結合できることを報

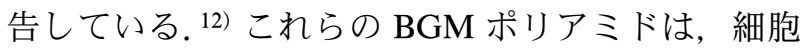
膜や核膜の透過性にも優れていることからも, 新し いアンチジーン療法として応用が期待されている.

また，Derven らは，G-C 塩基配列を認識できる化 合物をデザインし，二重鎖 DNA の任意の配列を認 識できる化合物 $[\mathrm{Py}, \mathrm{Im}$ からなる MGB] の開発に 成功している. ${ }^{52)}$ Boutorine らは, Py, Im, Hp から

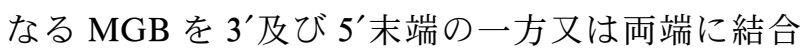
させた種々のコンジュゲート体を合成し，コンジュ ゲート体を含む二重鎖 DNA や三重鎖の性質を調 へ，配列特異的な安定化能を報告している. ${ }^{53)}$ 前述 した Hybrid 4 で修飾したオリゴヌクレオチドは, 副溝に位置するグアニン塩基部の 2 位のアミノ基に MGB を結合したもので，相補な DNA 鎖との二重 鎖の中央部の塩基配列を MGB が認識し，結合し二 重鎖を安定化できる.この特徵は，アンチセンスオ リゴヌクレオチドに適したものであると考えられ る. 今後は, 同様な修飾法によるオリゴヌクレオチ ドのピロールーイミダゾールポリアミド修飾体のア ンチセンス分子としての有効性を探りたい.

謝辞本研究は, 東京薬科大学薬学部で遂行さ れたものであり, 骨身を惜しまず本研究の推進役を 担って下さった当時の大学院生, 大庭勇介さん, 伊 藤大輔さん，また評価方法を飶切丁寧に指導して下 さった現千葉科学大学薬学部の照井祐介先生, そし て研究室に所属した学部学生さんの協力を得て行わ れたものであり心より感謝申し上げます．また，こ れまで長きにわたる大学での研究活動で大勢の諸先 生や諸先輩からの温かいご指導と多くの方々のご協 力ご支援あってこその今日であることを感じていま す．諸先生並びに支えて下さった卒業生，その他の 関係者の皆様に厚く御礼を申し上げます。 


\section{REFERENCES}

1) Milligan J. F., Matteucci M. D., Martin J. C., J. Med. Chem., 36, 1923-1937 (1993).

2) Thuong N. T., Hélène C., Angew. Chem. Int. Ed. Engl., 32, 666-690 (1993).

3) Uhlmann E., Peyman A., Chem. Rev., 90, 543 -584 (1990).

4) Fire A., Xu S., Montgomery M. K., Nature, 391, 806-811 (1998).

5) Stec W. J., Grajkowski A., Boszkowska M., J. Am. Chem. Soc., 117, 12019-12029 (1995) .

6) Matsuo M., Yagi M., Takeshima Y., Basic Appl. Myol., 13, 281-285 (2003).

7) Obika S., Nanbu D., Imanishi T., Tetrahedron Lett., 39, 5401-5404 (1998).

8) Gutierrez A. J., Froehler B. C., Biochemistry, 36, 743-748 (1997).

9) Nielsen P. E., Acc. Chem. Res., 32, 624-630 (1999) .

10) Cassiday L. A., Maher L. J-III., Biochemistry, 40, 2433-2438 (2001).

11) a) Kopka M. L., Yoon D., Pjura P., Dickerson R. E., J. Mol. Biol., 183, 553-563 (1985). b) Kopka M. L., Yoon D., Pjura P., Dickerson R. E., Proc. Natl. Acad. Sci. USA, 82, 1376-1380 (1985) . c) Iida H., Sugiyama H., J. Syn. Org. Chem., 58, 975-987 (2000).

12) White S., Baird E. E., Dervan P. B., Chem. Biol., 4, 569-578 (1997).

13) Dervan P. B., Bioorg. Med. Chem., 9, 22152235 (2001).

14) Marques M. A., Doss R. M., Urbach A. R., Dervan, P. B., Helv. Chem. Acta., 85, 44854517 (2002).

15) Baird E. E., Dervan P. B., J. Am. Chem. Soc., 118, 6141-6146 (1996).

16) Belitsky J. M., Beerman T. M., Dervan P. B., Bioorg. Med. Chem., 10, 3313-3318 (2002).

17) Gottesfeld J. M., Neely L., Trauger J. W., Baird. E. E., Dervan P. B., Nature, 387, 202205 (1997).

18) Trauger J. W., Baird E. E., Dervan P. B., J. Am. Chem. Soc., 120, 3534-3535 (1998).

19) O'Hare C., Uthe P., Mackay H., Blackmon K., Jones J., Brown T., Nguyen B., Wilson W. D., Lee M., Hartley J. A., Biochemistry, 46, 11661-11670 (2007).
20) Seio K., Mizuta M., Terada T., Sekine M., $J$. Org. Chem., 70, 10311-10322 (2005).

21) Huang L., Quada J. C. Jr., Lown J. W., Curr. Med. Chem., 2, 543-560 (1995).

22) Yamori T., Matsunaga A., Sato S., Yamazaki K., Komi A., Ishizu K., Mita I., Edatsugi H., Matsuba Y., Takezawa K., Nakanishi O., Kohno H., Nakajima Y., Komatsu H., Andoh T., Tsuruo T., Cancer Res., 59, 4042-4049 (1999).

23) Wang Y., Gupta L., Lown J. W., Anticancer Drug Des., 11, 15-34 (1996).

24) Edelson B. S., Best T. P., Olenyuk N., Nickols N. G., Doss R. M., Foister S., Heckel A., Dervan P. B., Nucleic Acid Res., 32, 2802-2818 (2004).

25) Fujiwara T., Tao Z., Sugiyama H., J. Am. Chem. Soc., 122, 7706-7707 (1999).

26) Tao Z., Fujiwara T., Saito I., Sugiyama H., $J$. Am. Chem. Soc., 121, 4961-4967 (1999).

27) Baraldi P. G., Nunez M. C., Tabrizi M. A., Clercq E. D., Balzarini J., Bermejo J., Estevez F., Romagnoli R., J. Med. Chem., 47, 28772886 (2004).

28) Kawashima E., Ohba Y., Terui Y., Kamaike K., J. Nucleic Acids. (in press)

29) Pelton J. G., Wemmer D. E., Proc. Nalt. Acad. Sci. USA, 86, 5723-5727 (1989).

30) Lown J. W., Krowicki K., J. Org. Chem., 50, 3774-3779 (1985).

31） Grehn L., Ragnarsson U., J. Org. Chem., 46, 3492-3497 (1981).

32) Boger D. L., Fink B. E., Hedrick M. P., J. Am. Chem. Soc., 122, 6382-6394 (2000).

33) Kawashima E., Itoh D., Kamaike K., Terui Y., Oshima T., Nucleos., Nucleot. Nucleic Acids, 22, 1309-1311 (2003).

34) Griffey R. H., Monia B. P., Cummins L. L., Freier S., Greig M. J., Guinoss C. J., Lesnik E., Manalili S. M., Mohan V., Owens S., Ross B. R., Sasmor H., Wancewicz E., Weiler K., Wheeler P. D., Cook P. D., J. Med. Chem., 39, 5100-5109 (1996).

35) Xu G., Buckheit R. W. Jr., Cushman M., J. Med. Chem., 44, 4092-4113 (2001).

36) Kamaike K., Kinoshita K., Niwa K., Hirose K., Suzuki K., Ishido Y., Nucleos., Nucleot. Nucleic Acids, 20, 59-75 (2001).

37) Adib A., Potier P. F., Doronina S., Huc I., 
Behr J.-P., Tetrahedron Lett., 38, 2989-2992 (1997).

38) a) Harris C. M., Zhou L., Strand E. A., Harais T. M., J. Am. Chem. Soc., 113, 43284329 (1991). b) Schmid N., Behr J.-P., Tetrahedron Lett., 36, 1447-1450 (1995) . c) Shinozuka K., Onodera M., Ikeda H., Sawai H., Chem. Lett., 31, 200-201 (2002).

39) Pittelkow M., Lewinsky R., Christensen J. B. Synthesis, 2195-2202 (2002).

40) Rentzeperis D., Marky L. A., Dwyer T. J., Geierstanger B. H., Pelton J. G., Wemmer D. E., Biochemistry, 34, 2937-2945 (1995) .

41) Loskotová H., Brabec V., Eur. J. Biochem., 266, 392-402 (1999).

42) Lah J., Vesnaver G., Biochemistry, 39, $9317-$ 9326 (2000).

43) Thomas M., Varshney U., Bhattacharya S., Eur. J. Org. Chem., 3607-3615 (2002) .

44) Watanabe K., Tanpakushitsu Kakusan Koso Bessatsu, 172-192 (1973).

45) Lee M., Rhodes A. L., Forrow S., Hartley J. A., Biochemistry, 32, 4237-4245 (1993).

46) Jain S., Zon G., Sandaralingam M., Biochemistry, 28, 2360-2364 (1989).

47) Kawashima E., Ohba Y., Terui Y., Kamaike K., submitted.

48) Kawashima E., Ohba Y., Terui Y., Kamaike K., Nucleic Acids Symp. Ser., 49, 327-328 (2005) .

49) Sinha N. D., Biernat J., McManus J., Köster
H., Nucleic Acids Res., 12, 4539-4557 (1984).

50) Kawashima E., Ohba Y., Kamaike K., Nucleic Acids Symp. Ser., 52, 387-388 (2008) .

51) Levina A. S., Metelev V. G., Cohen A. S., Zamecnik P. C., Antisense Nucleic Acid Drug Dev., 6, 75-85 (1996).

52) Szewczyk J. W., Baird E. E., Dervan P. B., Angew. Chem. Int. Ed. Engl., 35, 1487-1489 (1996)

53) a) Novopashina D., Sinyakov A., Ryabinin V., Venyaminova A., Boutorine A., Nucleos. Nucleot. Nucleic Acids, 22, 1179-1182 (2003). b) Boutorine A. S., Ryabinin V. A., Novopashina D. S., Venyaminova A. G., Helene C., Sinyakov A. S., Nucleos. Nucleot. Nucleic Acids, 22, 1267-1272 (2003) . c) Ryabinin V. A., Boutorine A. S., Helene C., Pyshnyi D. V., Sinyakov A. N., Nucleos. Nucleot. Nucleic Acids, 23, 789-803 (2004). d) Ryabinin V. A., Boutorine A. S., Helene C., Denisov A. Y., Pyshnyi D. V., Sinyakov A. N., Nucleos. Nucleot. Nucleic Acids, 23, 953-968 (2004). e) Novopashina D. S., Sinyakov A. N., Ryabinin V. A., Venyaminova A. G., Perrouault L., Brunet E., Giovannangeli C., Boutorine A. S., Nucleos. Nucleot. Nucleic Acids, 23, 1015-1022 (2004). f) Novopashina D. S., Sinyakov A. N., Ryabinin V. A., Venyaminova A. G., Halby L., Sun J.S., Boutorine A. S., Chem. Biodiversity, 2, 936-952 (2005). 